\title{
EL JUSTICIA DE ARAGÓN FRENTE A LA CIUDAD DE VALENCIA. UN CONFLICTO ENTRE OLIGARQUÍAS TERRITORIALES
} (1395-1404)

\author{
THE JUSTICE OF ARAGON VS. VALENCIA CITY. \\ A CONFLICT BETWEEN LOCAL OLIGARCHIES (1395-1404)
}

Agustín Rubio Vela Universitat de València

Resumen: Se aportan nuevos documentos inéditos procedentes de la serie de cartas misivas del Archivo Municipal de Valencia acerca del conflicto habido entre el Justicia de Aragón y la ciudad de Valencia, al intentar aquél aplicar su autoridad jurisdiccional sobre la baronía de Chelva en el reino de Valencia, por tratarse de una posesión nobiliar aragonesa sometida a los fueros de Aragón. Se resucitaba así el viejo problema del dualismo entre fueros de Aragón y Valencia en los dominios que la nobleza aragonesa seguía teniendo en el reino valenciano en el tránsito del siglo XIV al XV. Se interpreta el proceso fundamentalmente como un conflicto entre los intereses de las oligarquías de ambos reinos.

Palabras clave: Justicia de Aragón, Valencia, oligarquías, conflicto, siglos XIV-XV.

\begin{abstract}
This study provides new unpublished documents from the series of letters of Valencia Municipal Archives about a conflict occurred between the Justice of Aragon and Valencia City, when he tried to apply their judicial authority on the barony of Chelva in the Kingdom of Valencia, a specific possession of the Aragonese nobility under its jurisdiction. It rose so the old problem of dualism between Aragon and Valencia laws in some domains of the Valencian Kingdom still during $14^{\text {th }}$ and $15^{\text {th }}$ centuries. The process is interpreted mainly as a conflict between the interests of the oligarchies of both kingdoms.
\end{abstract}

Key words: Justice of Aragon, Valencia, oligarchies, conflict, $14^{\text {th }}-15^{\text {th }}$ centuries. 
Una de las epidemias de peste que asolaron Valencia en la Baja Edad Media pasó al recuerdo de las gentes asociada al nombre de Chelva, población de la comarca de Los Serranos que dista unos sesenta kilómetros de la capital. Fue la mortandad de 1395, la quinta desde que irrumpió el morbo en 1348, según el recuento, no del todo exacto, de Melcior Miralles: En l'any de M.CCC.LXXXXV., fonch la quinta mortaldat, la qual se deiu les morts de Xelva.Tan extraña denominación se debe a un episodio militar que se produjo ese mismo año, del que el dietarista también da cuenta: En l'any de .M.CCC. LXXXXV., a .X. de mag, anà la host de la ciutat de València a Chelva; e tornà la host en València a XXVII. de mag, en l'any damunt dit, ab victòria (Rodrigo, ed. 2011: 151-154). Esta resonante acción de la hueste de la ciudad contra Chelva, asociada en la memoria colectiva al brote epidémico, al que dio nombre, acabó con la toma de la localidad, cabeza del señorío del influyente noble don Pedro Ladrón de Vilanova. Apenas hacía un lustro que Juan I le había concedido el título de vizconde de Vilanova y de Chelva en atención a los servicios que había prestado tanto a él como a su padre, y considerando «que su linaje era muy antiguo y que por parte de su madre era muy propinco de la casa real» (Zurita, X, 44, vol. IV: 740-741). ${ }^{1}$

Es bien conocido el motivo de la intervención armada: los jurats de Valencia, en su condición de jueces de los emprius - derechos de aprovechamientos comunales - en todo el reino, incoaron proceso en 1392 contra el vizconde y su esposa, Violant de Boïl, por impedir, contraviniendo los furs y los privilegios de la capital, que pastaran en sus tierras de la vall de Xelva los rebaños de vecinos de aquélla. Tres años después, fracasados los intentos de concordia que se hicieron por iniciativas varias - del gobernador del reino, del batle general, del obispo-, el gobierno municipal valenciano acordaba sacar contra Chelva la milicia urbana, bien provista de ingenios bélicos y armamento para hacer frente a una posible resistencia. Partió el 10 de mayo de 1395 y se hizo dueña de todo el señorío: feren lurs proceïments tro a capció inclusive de la vila e de tots los castells, forces e lochs de la vall de Xelva. Tras lo cual fue vendido en subasta pública y comprado por la propia capital del reino (Sanchis, 1932: 85, nota; Vidal, 1974: 151-152; Rubio, 1989: 254; Rubio, 1999: 652-661; y Rubio, 2012: I, 174).

1 Además de esta distinción, «el primer título nobiliario valenciano concedido a un individuo ajeno a la familia real», le fue otorgado el ejercicio del mixto imperio y la alta y baja jurisdicción «sobre sus tierras en la Vall de Chelva (que incluía Domeño, Loriguilla, Sinarcas, Calles, Benaxex, las aldeas de Chelva, el castillo y la villa de Tuéjar con sus aldeas, el castillo de Sagra) y en Manzanera, en el reino de Aragón» (López, 2005: 71). 
No estamos ante un hecho insólito. En no pocas ocasiones Valencia se puso en pie de guerra para defender sus privilegios, libertades y emprius, tras entender los regidores que habían sido vulnerados (Rodrigo, 1975: 162-164). Ahora bien, esta vez la intervención habría de tener graves consecuencias, no sólo por la gran influencia del noble despojado del señorío, sino por una cuestión de naturaleza jurídico-política que convirtió el caso en un problema institucional: Chelva se regía por el fuero de Aragón, y el justicia aragonés intervino aduciendo que la villa, aunque ubicada en el reino de Valencia, era de su ámbito jurisdiccional; algo rechazado por los valencianos, para quienes el magistrado de Aragón carecía de autoridad en el territorio de su reino. Como es sabido, la pervivencia residual en éste del código aragonés produjo a lo largo de la época bajomedieval numerosos enfrentamientos entre las oligarquías de ambos reinos, en el curso de los cuales, más allá de lo estrictamente jurídico, solían enarbolarse armas sentimentales de signo patriótico (Rubio, 2012: 147193). El que estudiaremos aquí fue uno de ellos. Pero la abundante documentación epistolar que produjo, emanada de la escribanía de los jurats de Valencia, ${ }^{2}$ permite conocer con detalle $-\mathrm{y}$ desde la óptica de estos últimos, obviamente-, además de la confrontación con el justicia de Aragón, el desarrollo de las cortes de Zaragoza de 1398-1400, por lo que constituye un complemento de la información suministrada por el proceso, publicado recientemente (Navarro, ed. 2008) en el cual se basó Zurita cuando abordó el asunto, al que dedicó un capítulo en el libro $\mathrm{X}$ de los Anales.

En él se refirió a la acción militar de 1395 contra Chelva y su señor, el vizconde de Vilanova, que atribuye al gobierno local de Valencia y también - en esto se equivocó - al gobernador del reino. Ambos habrían procedido «desaforadamente» contra Pedro Ladrón y sus vasallos. El noble, desposeído del señorío valenciano, apeló al justicia aragonés, alegando que en él regía el fuero de Aragón: «firmó de derecho ante Juan Ximénez Cerdán justicia de Aragón, querellándose que se procedía contra él como no debía, siendo el val de Chelva y los castillos y lugares que en él se incluían poblados a fuero de Aragón». El magistrado, que ostentaba el cargo desde 1389 (Giménez, 1897: 338), citó al gobernador y oficiales de Valencia a comparecer ante él; al no ser obedecido, procedió contra ellos mediante el envío a Chelva de un portero real $\mathrm{y}$ un notario, que fueron apresados por el alcaide del castillo y procurador del señorío nombrado por los regidores valencianos (Zurita, X, 70, vol. IV: 851-

2 Se encuentra en la serie Lletres missives ( $L M$ ) del Archivo Municipal de Valencia (AMV). 
$852)^{3}$ Como éstos no reconocían los poderes jurisdiccionales que el justicia se arrogaba en los territorios valencianos regidos por el fuero aragonés, ${ }^{4}$ el viejo conflicto del dualismo foral resucitaba, esta vez con el agravante de la intrusión en un reino de una alta institución de otro. Era, sin duda, el objetivo del vizconde, persona próxima a la familia real, ${ }^{5}$ quien, al involucrar al dignatario aragonés, conseguía que su querella particular se convirtiera en cuestión política de alcance. El choque entre las instituciones y oligarquías de ambos reinos sería inevitable. Y, efectivamente, prelados, barones y caballeros aragoneses, considerando que la actuación de los ediles valencianos había constituido no sólo una agresión al justicia sino al reino de Aragón, a sus privilegios y libertades, se comprometieron a que, cuando fuesen convocados por el rey a la próxima asamblea parlamentaria, «no pasarían adelante en las cortes hasta que se hiciese cumplimiento de la justicia sobre aquel caso» (Zurita, X, 70, vol. IV: 852$)^{6}$

\section{Martín I en Zaragoza (1397-1400)}

Ese momento llegó en el reinado de Martín I, entronizado a la muerte de Juan I de Aragón (19 de mayo de 1396), su hermano. Un año después, tras dejar Sicilia, donde se encontraba cuando fue proclamado rey, llegó a Cataluña e hizo su entrada en Barcelona, para marchar luego a Zaragoza, donde habría de ser coronado solemnemente. Hizo su entrada en la capital aragonesa el

3 Vid. también Gual (1947-1948: 279).

4 Propiciaba el intervencionismo del justicia de Aragón en el reino valenciano un solapamiento entre lo geográfico y lo jurisdiccional, producto quizá de la separación que, tras las conquistas de Valencia y Mallorca, hizo Jaime I de los reinos de la Corona, realizada, según Sesma, «no tanto con fronteras geográficas, como, sobre todo, con límites jurisdiccionales: los Fueros de Aragón, los Usatges catalanes y los Furs de Valencia, marcarán radicalmente los territorios y, más concretamente, las áreas de influencia y gestión de cada uno de los grupos dirigentes». El mismo autor considera que la delimitación del espacio aragonés obedeció a criterios imprecisos hasta muy avanzado el siglo XIV: «pertenecían a Aragón las tierras regidas por los Fueros aragoneses o en las que tenía capacidad de intervención el Justicia de Aragón» (Sesma, 1988: 218 y 220).

5 María, esposa de Martín el Humano, distinguiría en enero de 1399 con la divisa de la Correa a la «nobla e amada nostra na Maria Ledro de Vilanova, doncella, filla del Vescomte de Vilanova» (Javierre, 1942: 115 y 209).

6 El historiador valenciano J. B. Perales, que sigue a Zurita, escribe que los aragoneses «juraron públicamente presentar su agravio á la consideracion de las primeras córtes que se celebrasen, ya fuesen generales o parciales, y no dejar que se terminasen hasta alcanzar completa reparacion de aquel ultraje, por el cual debia creerse ofendida toda la nobleza y lastimada en sus fueros y privilegios de señorío» (Perales, 1880: 357). 
7 de octubre de 1397, y el mismo día juró ante el justicia guardar los fueros. En abril del año siguiente convocó las cortes de Aragón, ante las cuales, el 23 de mayo, volvió a prestar el mismo juramento de guardar los fueros «a los perlados, barones, mesnaderos, caballeros, infanzones y a todos los otros del reino de Valencia que quisieron ser juzgados según fuero de Aragón y estaban sujetos al dicho fuero». En un célebre parlamento pronunciado ante la asamblea el 29 de abril, el soberano, después de dirigir frases de elogio a los aragoneses - ¡Loado sea Dios, qu'entre todas las naciones del mundo la fe desti regno es predicada e publicada por todas las nasciones! - , subrayó el papel relevante que tuvieron en la conquista del reino de Valencia: Et qui guarda l'ayuda que vosotros havez feyta a la conquesta de Valencia, por cierto que fue muyt grand e notable, hon diestes el cinqueno de toddo quanto havieç. Et aprés de los otros reyes no lo cale dezir (Zurita, X, 70, vol. IV: 831; Girona, 1916: 23; Tasis, 1957: 204; Palacios, 1975: 272-274; Cátedra, 19851986; 41-42).

Posiblemente la alusión no fuera casual. El soberano debía conocer la amenaza de los nobles aragoneses de paralizar las cortes si no ponía remedio al agravio sufrido por el justicia en el reino de Valencia al intentar ejercer su jurisdicción en el asunto de Chelva. Y, efectivamente, el asunto no tardó en surgir. El 30 de mayo de 1398, don Pedro Ladrón exponía su caso ante las cortes de Zaragoza, formulado en estos términos: el justicia no había curado provehir al requerimiento que él le hizo sobre la question mia de Chelva, por lo que de nuevo vos requiro que providedes en el dito feyto segund que vos yes estado requirido (Navarro, ed. 2008, vol. 1: 100). El justicia quedaba obligado así a explicar y denunciar ante las cortes el desacato a su autoridad de los oficiales de la baronía de Chelva y hombres de la ciudad de Valencia, que opusieron resistencia y encarcelaron al portero real enviado allí por él, y profirieron injurias contra su persona y magistratura $; 7$ por lo tanto, el hecho de que al vizconde de Vilanova no se le hubiera hecho justicia - argumentaba - no se debía a que él se hubiera inhibido, sino a la resistencia que encontró y a la imposibilidad de hacerle frente: por la difficultat del feyto no se havia podido

7 Según su versión, prendieron aquell de feyto e el notario e los testimonios qui con el yvan fuert innominosament, e por ciertos dias, aquellos tenieron en una mala presion la qual mas sabia pena o turment que custodia, e muytas palauras injuriosas dixeron no solament cuentra el dito portero mas encara cuentra mi e mi officio. Et apres de algunos dias el dito portero soltoron de la dita presion menaçandolo que si ell por la dita razon alli se tornava ellos lo enforcarian (Actas de las Cortes de Zaragoza de 1398-1400, vid. Navarro, ed. 2008, vol. 1: 100 y 101). 
encara exsecutar. Lo cual era muy grave, pues redundava en opprobrio de mi e del officio del justiciado de Aragon e de toda la cosa publica del regno de aquell, e en danyo e perjudicio del dito visconte. Por ello demandaba el apoyo del monarca para que su provisión fuese ejecutada, prendiendo la dita baronia si quiere vall e lugares de aquella a manos mias e de mi cort, e prendiendo los resistentes e tirando las fuerças al dito portero e a mi officio. ${ }^{8}$

El conflicto institucional entre dos reinos llegaba así a la monarquía, que se veía obligada a pronunciarse en una cuestión jurisdiccional que los valencianos consideraban absolutamente innegociable. La respuesta de Martín a las cortes llegaría el 4 de junio. Señaló cómo los embajadores de la ciudad de Valencia y otros habían denunciado ante él, a propósito del mismo asunto, la actuación del justicia de Aragón, considerando que es en gran prejudici de la dita ciutat e de sos privilegis e libertats. Ante las dos demandas, la respuesta dilatoria era la única posible para el monarca en aquellos momentos: per ço diu que oydes les parts fara bona e espatxada provisio en lo dit fet segons per justicia trobara esser fahedor. ${ }^{9}$ Efectivamente, los jurats habían hecho llegar al rey su versión del asunto, como indica la correspondencia con Andreu Guardiola, hombre de confianza e informador de aquéllos en la corte zaragozana. ${ }^{10}$ En la carta que le dirigieron el 5 de junio se lamentaban de que el caso estuviera siendo aprovechado por algunos para enemistarlos con el rey, y esgrimían la idea, repetida hasta la saciedad, de que la intervención militar de Valencia en el señorío tuvo como objetivo la defensa de los intereses de la corona, por lo que la ciudad era merecedora de la gratitud real, no del reproche. ${ }^{11}$

El monarca, acuciado por necesidades económicas, necesitaba que las cortes aragonesas aprobaran su donativo. Como éstas ponían como condición previa, para proseguir los debates, que solucionara satisfactoriamente el agra-

8 Actas de las Cortes de Zaragoza de 1398-1400, vid. Navarro (ed. 2008, vol. 1: 100 y 101-102).

9 Actas de las Cortes de Zaragoza de 1398-1400 (Navarro, ed. 2008, vol. 1: 104). En la sesión del 20 de junio, el monarca insistió en la necesidad de oir a las dos partes y en su voluntad de justicia y concordia: nos hi provideremos e por utilidat del uno e del otro regno traballaremos en el dito feyto que binga a buena concordia (Navarro, ed. 2008, vol. 1: 109). Cf. Zurita, X, 70 (IV, 853).

10 El 23 de julio le pedían que en tot cas e manera tengats los ulls e les orelles prestes als fets de Xelva e als tractes e fets de mossén Pere Ladró, e de tot nos certifiquets sovén (AMV, LM 6, f. 29v).

11 Car la ciutat, qui ha fet son bo e just procés en servii e utilitat del senyor rey e de ses regalies e superioritat, no està ab temor, mas ab ferm cor e ab propòsit de haver-ne del senyor rey, no blasme, mas gràcia e remuneració, e de esser-ne en perpetual fermetat ab tot afronte de mostrar e haver lo mal procés del justícia d'Aragó, salva sa honor (AMV, LM 6, f. 5r; 1398, junio, 5). 
vio sufrido por el justicia (que supondría a su vez la devolución de Chelva al vizconde), y la poderosa ciudad de Valencia se oponía rotundamente al reconocimiento de la autoridad del dignatario aragonés en el territorio de su reino, las tensiones comenzaron a dispararse. Era evidente la dificultad de encontrar una fórmula que permitiera eliminar el obstáculo que hacía imposible el avance de las cortes de Zaragoza. De ahí la necesidad de Martín el Humano de encontrar un mediador eficaz, un hombre que contara con su confianza y con la de la oligarquía de Valencia. Y lo creyó encontrar en la persona del entonces obispo de Tortosa, Hug de Llupià, que velaba por los intereses de Valencia en la corte real y a quien los jurats correspondían dando apoyo a su pretensión de conseguir la mitra valentina, a la sazón vacante ${ }^{12}$ lo que muy pronto se haría realidad: el 28 de noviembre de ese mismo año de 1398, Llupià sería nombrado por el papa obispo de Valencia (Olmos, 1949: 103).

\section{Las razones de Valencia}

Meses antes, el 12 de junio de 1398, el prelado era destinatario de una enjundiosa y reveladora misiva de los regidores valencianos, muestra de la tensión política creada en la corte de Zaragoza. ${ }^{13}$ En ella le proporcionaban información sobre los affers de Xelva y se quejaban de que la intervención militar de la ciudad hubiese sido presentada al rey de manera tergiversada, como algo contrario a sus intereses, pues se actuó més per mantenir ses regalies e superioritat que per bé d'altri. Por otro lado, en lo relativo al conflicto con el justicia de Aragón, afirmaban que tanto sus predecesores, los jurados de entonces, como el gobernador del reino le habían manifestado por escrito su rechazo, jurídicamente fundamentado, de cualquier injerencia en el reino: per lurs letres han dit e al-legat, per veres e clares raons, al justícia d'Aragó que ell no's podia ne pot entrametre, ne era ne és jutge d'aquest fet, no solament segons nostre fur e segons dret comú, ans encara segons lo fur d'Aragó mateix. También le habían propuesto estudiar conjuntamente la cuestión con expertos en derecho, en lugar conveniente acordado por ambas partes, y había rehusado hacerlo, deint o al-legant que ell tenia loch cert de fer sos juhís, ço és, la ciutat de Çaragoça, e que si los dits governador e jurats volien res al.legar o mostrar, que anassen denant ell.

12 Escribieron cartas al papa, al rey y al cardenal Boïl (AMV, LM 6, ff. 11v-14r; 1398, junio, 17).

13 Publicada en el apéndice: doc. núm. 1. 
La carta da cuenta asimismo de que las actuaciones del justicia y del vizconde eran vistas en Valencia como un intento de magnificar el asunto, dándole un cariz de agravio a los aragoneses, algunos de los cuales parecían dispuestos incluso a tomar las armas y dirigirse al reino de Valencia con el apoyo de las cortes: que més se fa per tal que tota la cort se concorde a la opinió d'alcuns qui entenen que l dit justícia, ab les osts d'Aragó, poderosament deja venir a Xelva per haver aquella a sa mà, si porà, e si no, per damnejar a nosaltres o a coses nostres. Terminaban diciendo los ediles, como respuesta a esa amenaza de dirimir la controversia no per dret, mas per força, que sabrían defenderse: com del tot los aragoneses volguessen venir, axí com dit és, e no sia pus en nosaltres, invocam sobre açò lo testimoni de Déu e del món, e, ab ajuda sua, per nostra defensió, entenem fer de manera que ells no:s puxen jactar ne gaubar de lur errada.

Tal amenaza planearía sobre la organización de la cruzada naval contra los musulmanes norteafricanos que por entonces se preparaba en Valencia, donde se esperaba la llegada de cristianos dispuestos a embarcarse para combatir (Ivars, 1921: LXII). De ahí que en la misma misiva denunciasen los jurats que una acción bélica de los aragoneses en el reino supondría torbar aquesta santa armada, lo que sería gran càrrech en deservir de nostre senyor Déu e en dan e vituperi de tota christianitat. Los rumores se acrecentaron a mediados de junio. Los ediles escribieron a Alpuente, Llíria, Chelva, Jérica y otros lugares para que estuvieran atentos a la posible llegada de aragoneses que, con apariencia de cruzados, pretenderían en realidad apropiarse de algún castillo o fortaleza en la comarca de Chelva: Ara havem sabut que alcunes companyes d'aragoneses, ab capitanis en àbits d'ermitans e beguins, signats de la sancta creu, sots color e fama que han mesa d'anar en aquesta sancta armada contra moros, deuen venir per vostres partides a Xelva secretament per assajar de furtar, si poran, qualque castell o força d'aquell riu. En la enviada a Chelva se lee: alcuns aragoneses ab capitanis d'ermitans o de beguins, sots color d'anar en la sancta armada, se sien ajustats en gran nombre, mas secretament per venir a Xelva. Pronto se demostró que el temor era infundado. ${ }^{14}$

En julio, el secretario real Juan de Tudela informó a los jurats del deseo de Martín I de tratar con ellos sobre los affers de Xelva, por lo que pedía a la ciudad que enviase embajadores a Zaragoza, a los que aseguraría de tota 
marcha e represàlia del justícia d'Aragó. En una misiva fechada el 24 de dicho mes, ${ }^{15}$ respondían que, para hacer lo que el rey solicitaba, era preceptivo convocar antes un consell general con participación de alcuns notables hòmens, axí doctors com ciutadans, qui en los dits affers han tenguda la mà $e$ hi saben molt, muchos de los cuales se encontraban ausentes. No era posible aprobar de inmediato el envío de la embajada. Ahora bien, dada la trascendencia del asunto, se sentían obligados, por la fidelidad debida, a informar al monarca, secretamente, de que negociar sobre los affers de Xelva, dada la situación en que se encontraban entonces - en los térmens que huy són-, sería gravemente perjudicial para la ciudad; además, la pretensión del justicia de Aragón de tener jurisdicción en el reino de Valencia no podía ser objeto de negociación, pues usurpa vostra juredicció, superioritat e regalia, e prejudica e plaga nosaltres en nostre dret. Era imposible un acuerdo, pues ello supondría consentir-li sa usurpació e approvar-li sa error. Asimismo se negaban a aceptar que el asunto se tratase en el reino de Aragón, en via judiciària o arbitrària o de col·lació, pues crearía un precedente y el daño sería ya irreparable que la juredicció del justícia a lur intenció fos approvada e perpetuada. Los ediles anticipaban al soberano su convicción de que el consell aprobaría el envío de missatgers, pero sólo por complacerle y con fines exclusivamente informativos, esto es, sin poderes para alcanzar un compromiso mientras él permaneciera en Aragón, circunstancia podría ser aprovechada allí por algunos para dar destorp a nostres affers, major que no han fet tro ací. com del tot los aragoneses volguessen venir, axí com dit és, e no sia pus en nosaltres, invocam sobre açò lo testimoni de Déu e del món, e, ab ajuda sua, per nostra defensió, entenem fer de manera que ells no·s puxen jactar ne gaubar de lur errada.

En agosto, y también por medio de su fiel secretario Tudela, Martín I pedía por segunda vez el envío de missatgers para tratar del asunto de Chelva, con o sin poderes para firmar un acuerdo, y daba garantías de que estarían a salvo de tota represàlia e procés del justícia d'Aragó. Los jurats dieron su respuesta en una misiva en la que informaban al rey de que los elegidos para la embajada - sens alcun poder - se presentarían ante él con credenciales e informacions faents per aquesta cosa, los quals secretament e en apart, fora juhí, informaran vostra senyoria del dit fet ${ }^{16}$ En los meses siguientes, la correspondencia

15 Publicada en el apéndice: doc. núm. 2.

16 MV, $L M$ 6, f. 42r-v (1398, agosto, 21). 
da cuenta de la presencia y gestiones de los embajadores, cuya misión - se subrayaba - era de carácter exclusivamente informativo. ${ }^{17}$

\section{Represalias del justicia}

Las seguridades dadas por el soberano se debían a que en Zaragoza habían comenzado acciones de represalia contra valencianos, ordenadas por el justicia de Aragón. La carta a Llupià, ya comentada, del día 15 de junio, revela que no se libraron de ellas los propios embajadores de Valencia: cascuns missatgers que hajam trameses al senyor rey en Aragó, per aquests e altres affers, lo dit justícia ha marchats e penyorats, faent pendre les cavalcadures, libres e robes lurs e de lur companya, contra privilegi de libertat e segurtat de missatgers, ço que hanc no fo fet en terres de tartres e de turchs ne d'altres. Con estas duras palabras se referían a unas represalias que se prolongarían en el tiempo. La más resonante y conocida, pero no la única, fue la incautación de los cofres con el equipaje de los representantes de Valencia enviados a Zaragoza para asistir a la ceremonia de coronación del rey Martín (Zurita, IV, 851-853; Gual, 1947-1948: 279-280).

Otra misiva que los ediles dirigieron en noviembre de 1398 a Ramon de Soler, uno de los miembros de aquella embajada, pone de manifiesto que la gestión diplomática en Zaragoza se estaba desarrollando con normalidad gracias al salvoconducto real, pero que el temor a las represalias del justicia de Aragón constituía ya un obstáculo serio para cualquier actividad económica con Valencia. De ahí que encontraran dificultades insalvables para hacer llegar dinero a la delegación: D'aquests dies, en una letra fem menció que nostre clavari vos trametia diners per via de cambi, car axíns ho havia dit. E ara havem sabut ab gran desplaer que no féu, ne troba encara ara persona e.l món ab qui faça cambi, ne·ls vos puxa en altra manera trametre, car, per dupte del procés del justícia d'Aragó, tothom se és retret e·s retrau de fer aquí affers, e mils se trobarien cambis aquí que ací. E axí, fèts cercar, si trobaríets cambi alcú, e prenets-lo tro cent cinquanta florins..$^{18}$

17 AMV, LM 6, ff. 51r-52v (1398, septiembre, 14 y 20). El 6 de octubre: En la letra del primer plech se contenia lo lonch raonament que haviets haüd primerament ab lo senyor rey, recitan-li les summes de les escriptures que us haviem trameses; segonament, ab son vicecanceller e altres de son consell, no pas en figura de juhí, mas fora aquell, amigablement, per lur informació, de què par ells sien en bona opinió; de la qual cosa havem haüd subiran plaer ab retiment de gràcies a nostre senyor Déu e ab loament de vostra molt sàvia diligència (ibid., f. 57r).

18 AMV, $L M$ 6, f. 75r. El subrayado es nuestro. 
A pesar del salvoconducto regio, en las primeras semanas de marzo de 1399, otro de los embajadores, el jurista Guillem Çaera, estuvo a punto de ser encarcelado en Zaragoza por orden del justicia de Aragón, según informó Jaume de Celma a los jurados. Si pudo esquivar la prisión fue porque tuvo noticia antes y partió a escondidas. ${ }^{19}$ La gravedad del hecho era patente. El mismo día, los ediles se dirigían a Guillem Çaera, missatger de la ciutat de València en cort del senyor rey, ${ }^{20}$ para informarle de que habían escrito al obispo Llupià dándole cuenta del asunto: l'honorable micer Guillem Çaera, missatger d'aquesta ciutat en cort del senyor rey, informat que a instància de mossén Pere Ladró devia esser pres per lo justícia d'Aragó o per lo fet de Xelva, s'és haüd absentar per no venir en mans del dit justícia. En la misiva se mostraban confiados en que el prelado protegería al missatger, de cuyo paradero no tenían noticia: del qual encara, e de sos fets, no sabem com li és avengut, jassia hajam ferma sperança que, pus vós, senyor, hi siats estat a temps, aquell no haurà encorregut alcuna lesió o dampnatge. Y solicitaban su intervención ante un hecho cuya gravedad aumentaba si se tenía en cuenta la circunstancia: fue el propio monarca quien había llamado al jurista a comparecer ante él. ${ }^{21}$

La tensión alcanzó su cenit en las semanas previas a la ceremonia de coronación, que tuvo lugar el 13 de abril. El 18 de marzo, antes de que partiese la delegación que había de representar a la ciudad de Valencia en la solemnidad, los ediles redactaban una carta para el monarca, que Jaume de Celma había de entregarle en mano en Zaragoza. El texto es de sumo interés por cuanto indica que, por informaciones que les habían hecho llegar secretamente, sabían que el vizconde de Vilanova se había jactado de que, a instancias suyas, el justicia de Aragón, confiscaría las cabalgaduras y equipaje de todos los miembros de aquélla: Ara, alcuns amichs nostres de vostra reyal cort, senyor, han-nos tramés a dir secretament que ells, de pregon secret, saben e són certs que ll vezcomte de Vilanova ha delliberat e ja emprés ab lo justícia d'Aragó que, venguts e estants en vostra cort los dits missatgers, faça marchar e penyorar aquells per lo dit justícia, jactant-se

19 En una letra que vós nos trametés pochs dies són passats, és expresat que l'onorable micer Guillem Çaera fóra estat detengut a presó per lo justícia d'Aragó si no fos estat sentiment que n'hauria haüd (AMV, LM 6, f. 123r-v; 1399, marzo, 14).

20 AMV, LM 6, f. 123v-124r (1399, marzo, 15): Per letra d'En Jacme de Celma sabem que mossén Pere Ladró havia request lo justícia d'Aragó que de vostra persona fes presó e aprés execució, axí com a encartat per lo fet de Xelva, e en vostres béns per via de marcha execució; e com fóra estat fet si no n'haguéssets haüd sentiment, per què us covench a absentar; e, finalment, com vós hic fórets partit d'amagat, sinó que·l senyor bisbe ho havia fet cessar tro a tant que n'hagués parlat ab lo senyor rey.

21 Doc. núm. 3 del apéndice. 
ab alcuns amichs seus en secret que ara farà fer gran bol de les quavalcadures e roba dels dits missatgers e de lurs companyons, escuders e altra companya, qui seran en gran nombre. Los jurados subrayaban la gravedad de una acción así, no sólo por la ofensa que supondría para la ciudad, sino porque empañaría la solemnidad de la fiesta: La qual cosa, senyor, si s fahia, ço que a Déu no plàcia, seria àls, en quant fos en los dits justícia e vezcomte, sinó torbar la festa e solemnitat de la dita coronació o detraure a la honor d'aquella e, per consegüent, de vós, senyor, e voler fer minva a aquesta ciutat, servint a la vostra reyal senyoria més avant, car los ja elets missatgers o altre no farien ne fer volrien tal missatgeria per esser escarnits e aminvats. De ahí que, antes de que los embajadores partiesen, pidieran seguridad; si no era posible, el rey habría de excusar la presencia de Valencia en los actos: On, senyor, si la vostra excel-lencia vol o entén que.ls dits missatgers poden anar, estar o tornar en segur de totes represàlies o penyores et de tot altre procés del dit justícia d'Aragó per los affers del dit vezcompte e de qualssevol altres, sia vostra mercé, per vostra letra, certificar-ne nosaltres encontinent sens tota reig, de manera que puxam spatxar los dits missastgers e ells puxen de fet partir. La qual cosa, en tal cas, serà complida de fet, Déu ajudant. En altra manera, que sia vostra mercé, senyor, haver ells e nosaltres per scusats de lur anada, car tothom rahonable pot conéxer que no.s dina de bon plaer aquell qui aprés lo dinar espera sa minva e son dan.

La respuesta debió de ser positiva, pues los embajadores partieron el 24 de marzo con credenciales para el rey, la reina y Hug de Llupià, ya obispo de Valencia. ${ }^{22}$ Unos días después llegaban a Zaragoza y tuvo lugar el resonante suceso que relata así Zurita: «continuándose las cortes y estando el rey para celebrar la fiesta de su coronación, llegaron los mensajeros de la ciudad de Valencia que venían en nombre de aquella ciudad para asistir a ella con gran acompañamiento; y por mandado del justicia de Aragón se ocuparon sus cofres y todo lo que traían, y por respeto y acatamiento de la fiesta los dio en fiado» (Zurita, Lb. X, cap. 70, vol. IV: 853).

\section{La parálisis de las cortes aragonesas}

Las cortes aragonesas siguieron paralizadas. A finales de mayo de 1399, los jurats escribían a Llupià, obispo y valedor de la ciudad - aquella no aja de present altre protector sinó vós, senyor, qui per gràcia de Déu sòts nostre 
prelat e nostre pare speritual - , para expresarle su profundo malestar por que la asamblea de Zaragoza, según noticias llegadas a ellos, había conseguido que el rey, cediendo a tan prolongada presión, hubiera decidido devolver Chelva al vizconde, y que sólo por encontrarse enfermo no se había presentado en la baronía para hacer efectiva la entrega: la cort d'Aragó ha dit, per final resposta al senyor rey, de no fer res sobre ço que $\cdot l$ s ha demanat tro a tant que $\cdot l$ dit senyor realment aja presa e haüda a sa mà la nostra vall de Xelva, per retre aquella al vezcomte. E que $\cdot$ l dit senyor axi.ls ho ha atorgat. E de fet se aparellava e fóra vengut a Xelva si no l'agués enbargat accident de la sua molt excel-lent persona. Exponían con detalle los argumentos, de diversa naturaleza, por los que rechazaban rotundamente una acción de esa naturaleza, que, en caso de hacerse realidad, supondría un triunfo del justicia de Aragón sobre la propia soberanía real; por ello — afirmaban - Juan I la había descartado: lo senyor rey En Johan, de bona memòria, importunament suplicat per part del vezcomte e dels aragonesos a pendre's Xelva en via de seqüestre, no.ls volch escoltar, dehint que, per poder que n'haguessen, no soferria sobiran lo justícia d'Aragó, ne altre en regne de València n'és, si tolria un pèl de la sua reyal superioritat. Y, tras acusar al noble de intentar un engaño, señalaban que la verdadera raíz del problema no era la posesión de Chelva, sino la pretensión del justicia de tener jurisdicción en el reino: lo venir a les armes no vé per raó de la possessió que nosaltres havem de Xelva, mas vé per la juredicció que.l justícia d'Aragó pretén haver en regne de València, en los lochs poblats a fur d'Aragó, e per la juredicció que nosaltres havem en aquells. Per què, si seqüestre se havia a fer, se hauria a fer de les jurediccions e no pas dels lochs de Xelva. ${ }^{23}$

La tensión prosiguió durante el verano de ese año de 1399. Por un lado, en Zaragoza seguían ejecutándose las medidas de represalia contra los valencianos. El 23 de junio, un jurista, misser Francesc Tallat denunciaba ante el consell de Valencia que había sido penyorat e marchat en Caragoça per lo justícia d'Aragó o commissari seu, no per culpa ne per fets propris del dit micer Francesch, mas per los affers de la ciutat, ço és, per lo fet de Xelva. ${ }^{24}$ Por otro, la presión de las cortes aragonesas sobre el rey hacía temer en Valencia una decisión contraria a sus intereses. En junio, los jurats siguieron enviando cartas a Llupià sobre el fet de Xelva en las que mostraban su con-

23 Doc. núm. 4 del apéndice.

24 AMV, Manuals de consells 21, f. 270v. 
fianza en el monarca: no cre[e]m que $\cdot$ l senyor nos vulla fer tan gran tort $n i$ tan gran injustícia que.ns prive de nostra possessió, la qual ab gran justícia tenim e havem, e tendrem, si a Déu plau, mijançant la justícia del senyor rey e la ajuda vostra. ${ }^{25}$ Pero esas manifestaciones son la prueba de su temor a que el poder del adversario hiciera mella en Martín I: E si ells, ab porfídia o importunitat, cuyden obtenir del senyor rey ço qui just no és, creem fermament que nosaltres, ab raonable, instant, humil e esforçada supplicació, bé obtendrem del dit senyor ço que just és, lo cor del qual és en la mà de Déu e li farà conèxer son gran prejudici e nostra justícia, e foragitar la maestria dels adversaris. ${ }^{26}$

Los valencianos sabían que el hecho de encontrarse el rey en Zaragoza celebrando cortes jugaba en contra de sus intereses. De ahí que procuraran tener noticia puntual de todo cuanto allí sucedía en relación con el asunto de Chelva, para lo cual contaban con personas que realizaban tareas de espionaje y les suministraban información. ${ }^{27}$ A veces llegaban rumores falsos, creados tal vez interesadamente para causar inquietud, como el que había dado lugar a la carta a Llupià del 31 de mayo, antes mencionada, acerca de la decisión real de devolver de inmediato al vizconde la baronía. A finales de agosto, ese rumor se había extendido tanto que llegó a provocar fuerte desasosiego en la zona: tots los habitants en la dita vall són molt espaventats per tal com seria estat dit aquí que lo senyor rey deu venir en aquexes partides per haver a mans sues la vall de Xelva e per restituir aquella al vezcomte, e semblants paraules, de què ells estan molt dubtoses e malcorats. Los jurados lo desmentían y se mostraban confiados en que la justicia real les daría la razón: Car la ciutat, qui d'açò ab gran raó e justícia se és emparada, darà remey, Déu vo-

25 AMV, LM 6, f. 166r-v (1399, junio, 12). Y el día 28 del mismo mes: No $s$ pot acostar a nostra creença que·l senyor rey, qui d'alta saviea, per gràcia de Déu, és dotat, no conega lurs barats, e son gran e irreparable prejudici a nostra dretura, e que no do son dret a cascú e sa justícia, la qual és de tal virtut que, bé que a vegades parega esser acabuçada, però, a la final tots temps sura o roda sobre tota iniquitat e fa sa justa operació (ibid., ff. 171v-172r).

$26 \mathrm{AMV}$, LM 6, f. 172v (1399, junio, 28): carta al molt honorable e savi sènyer En Ramon Baró, escrivà del senyor rey.

27 Uno de ellos era Ramon Baró, de la scrivania del senyor rey, citado en la nota anterior, al que mandaron la misiva de Llupià para que se la entregara directamente, le pidiera respuesta en breve, y los mantuviera informados: E com hajam entés que l fet de Xelva retorna e gruny en cort, pregam-vos, en tan car com podem, que us en prengats esment e hi tengats ubertes ulls e orelles quedament e secreta. $E$ de tot ço que $n$ porets saber o sentir, nos en certifiquets per vostres letres a cascú acte per cuytat correu. E si per algunes coses lo senyor rey exia de Saragoça per anar engalt, per cuytat correu nos certificats, e no·ns hi plangats correus, car aquells fets nos són tan cars que pus no porien (AMV, LM 6, ff. 159v-160r; 1399, mayo, 31). 
lent, e per justícia defendrà la dita vall denant lo dit senyor, qui, axí com a bon rey e just, donarà a València sa justícia e al vezcomte la sua. ${ }^{28}$

Los embargos de bienes de valencianos en Zaragoza obstaculizaban la comunicación entre la ciudad de Valencia y el rey. En noviembre, sin ambages, aunque en términos corteses, los ediles manifestaban a éste su malestar por la impunidad con que se cometían tales acciones, que les obligaban a ser reacios al envío de missatgers a la corte aragonesa: volenterosament a vostra reyal presència [...] trametèrem nostres missatgers, qui ab viva veu raonassen nostre fet e nostre dret, mas no.ns és avinent, contrastant l'embargament de fet del justícia d'Aragó, de què diverses e moltes vegades a la vostra senyoria supplicat havem de remey de justícia covinent, e no ha plagut a Déu ne a aquella que y sia estat proveït, no contrastant que fer-se degués e deja, per dret comú e per ús de totes les nacions del món, e per singular e exprés privilegi reyal que n'havem. E res no.ns hi val, ne vostra personal e molt desijada presència vol Déu que venga e sia ací. De manera que aquí e ací freturam de vostra facial vista, que $n$ s és sobres greu entrenyor e dan. $Y$, tras indicar que no se sentían merecedores de un trato así, lanzaban esta frase hiriente: Però, senyor, encara farem nostre poder de enviar a la vostra senyoria missatgers, encara que sàpien anar ab bèsties d'aventurers. ${ }^{29}$

\section{Búsqueda de una solución}

Evidentemente, el primer interesado en encontrar una salida a la difícil situación era el soberano, que por medio de Llupià propuso a los regidores de Valencia una fórmula que suponía para éstos ceder en su hasta ahora firme postura. Pero la carta que dirigieron al prelado el 22 de octubre - carta secreta en la que exponían sus puntos de vista al rey, a petición, también secreta, de éste - demuestra que se mantuvieron absolutamente inflexibles en el rechazo tanto a la devolución de Chelva al vizconde como al reconocimiento de la jurisdicción del justicia de Aragón en el reino. En ella condenaban con energía el proceder de las cortes aragonesas, acusándolas de condicionar el donativo a la realización de un acto injusto por parte de la corona: En bona fe, tal merca-

28 Carta a Pere de Solanes, alcaide y procurador de Chelva (AMV, LM 6, f. 206v; 1399, agosto, 27). El 7 de enero de 1400 , en otra dirigida a los jurados, prohombres y alamines y viejos del valle de Chelva, desmentían de nuevo el rumor de la vuelta del señorío a manos del vizconde (ibid., ff. 275v-276r).

29 AMV, LM 6, f. 254r-v (1399, noviembre, 25). 
deria no.s cové als demanadors, e molt menys al senyor rey, no solament per aquella quantitat de moneda, mas encara per tot l'or del món. Y reiteraban su parecer sobre las competencias que se atribuía el justicia: aquest fet toch capital prejudici del senyor rey e de la sua corona e preheminència, com no sia àls sinó constituir-li subirà en aquest regne, axí com en Aragó, e tolre-li les sues superioritats e preheminències reyals, la qual cosa és esquivadora axí com a foch cremant ${ }^{30} \mathrm{La}$ actitud inflexible de la ciudad, reiterada en una nueva carta a Llupià fechada el 19 de diciembre, ${ }^{31}$ como es obvio, suponía un serio obstáculo para los objetivos inmediatos del Humano - acabar con la inactividad de las cortes aragonesas -, por lo que las relaciones entre ambos comenzaron a enturbiarse en los últimos meses de 1399.

Se vino a añadir entonces un nuevo factor de tensión, el estado de salud del soberano, quien el 9 de diciembre de aquel año se dirigió por carta a Pere d'Artés, maestre racional y hombre de prestigio intelectual en Valencia (Girona, 1916: 64 y 81). ${ }^{32}$ Tras informarle de que el obispo Llupià, su consejero, scriu als jurats d aquexa ciutat sobre l fet de Xelva per sa letra molt estesament, y de que, debido a la enfermedad que padecía, los médicos le aconsejaban exir d aquesta terra qui es molt freda e a nos molt contraria, le instaba a conseguir, poniendo para ello todos los medios a su alcance, que los jurats aceptaran sin dilación lo que el prelado les proponía: complesquen ab acabament e fort breu ço de que ls scriu lo dit bisbe (Girona, 1916: 68).El 19, sabedores ya de la quebrantada salud del rey, los ediles lo animaban, por medio de su prelado y consejero, a emprender viaje, subrayando lo beneficioso del clima de aquesta ciutat, que és terra calda o temprada per a sa complexió, en la qual cobrarà, fiam en Déu, plena sanitat de cos e de ànima; además, en la ciudad podrían abordar directamente y con libertad el conflicto con el vizconde de Vilanova, $e$ respondre'n clar al dit senyor, ço que ara fer no pot bonament estant axí prejudicada, marchada e maltractada per lo dit justícia d'Aragó. ${ }^{33}$ Pero en la misiva no daban la respuesta que el rey les pedía sobre Chelva. Ello se explica por el extremado sigilo con que se llevó a cabo el negocio.

Desde Zaragoza, sometido a la presión de las instituciones de Aragón, el rey formuló secretamente su propuesta por medio de Llupià. ${ }^{34}$ Los jurats reci-

30 Doc. núm. 5 del apéndice.

31 Doc. núm. 6 del apéndice.

32 Sobre Artés, vid. De Riquer (1980, vol. II: 138, 148-149 y 440) y Eiximenis (ed. de Wittlin, 1983: 8 y 37)

33 Doc. núm. 6 del apéndice.

34 Éste recibiría la respuesta de los jurats el 14 de enero. Vid. Girona (1916: 24, 41 y 81). 
bieron dos cartas, una del soberano, escrita de su propia mano, y otra del obispo, a nosaltres secretament liurades por Pere d'Artés y Nicolau Pujada, el batle general. Se les exigía que las mostraran a muy pocas personas, y bajo juramento de no revelar el contenido: volgueren de nosaltres de tenir secret ço que en aquelles és contengut, sinó a fort pochs en nombre, e ab sagrament, axí com advocats, síndich e escrivà nostres. Pero, una vez leídas, considerando que no podían actuar sin que el consell general conociera lo propuesto, dada su importancia, pidieron a los intermediarios que consiguieran la autorización del rey para que las misivas fuesen leídas y debatidas en una sesión plenaria del consistorio, antes de la cual cada uno de los consellers juraría guardar secreto. No obstante, los ediles no ocultaron su opinión contraria a lo propuesto por el monarca, argumentando: ello exigiría la aprobación de las cortes del reino, donde se opondrían quienes tenían intereses similares a los del vizconde y sus afectos; además, los aragoneses no se considerarían vinculados a una decisión tomada por parte ajena; entre las gentes de Valencia, plenamente convencidas de que la justicia daría la razón a la ciudad, sembraría confusión y suscitaría desconfianza. ${ }^{35}$

¿Qué proponía el rey? Su objetivo, obviamente, era no contrariar a los aragoneses en aquellos momentos con un fallo que negara la capacidad jurisdiccional del justicia de Aragón en el reino de Valencia. Que era lo que pretendían los valencianos, insistentes en la idea de que la cuestión había de quedar zanjada judicialmente por el monarca: a la sua preeminència pertanga conèxer aquesta disceptació, ço és, si lo justícia d'Aragó pot esser son subirà e nostre jutge en aquest regne o no, o si lo vezcomte, qui-s clama de nostre procés, s'i és bé e justament fet o no. Convencidos de que en totes aquestes coses la ciutat haja gran e clar dret, descartando la posibilidad de una actuación injusta por parte de la corona y dando por supuesta su capacidad para hacerse obedecer, la única solución posible era una sentencia de Martín I, oidas ambas partes, y ajustada a derecho: que a la beneyta ora, convocades les parts, ell faça la justícia que.s pertany entre aquelles, e no prejudique a nenguna d'aquelles

35 E hauria infinits contradictors, vulla's de braces per lur interés de cases semblants, vulla's de singulars parents e amichs del vezcomte. E, on encara axí passàs, los aragoneses porien al-legar que allò no $l$ s prejudicaria, car seria res inter alios acta, e nosaltres tendríem ja a dors lo prejudici passat. E que l'acte cuydat de cort, cuydant adobar aquell, se valgués poch, romandríem confuses e a bona fe, senyor, ab tant perill de la gent com nosaltres sabem, qui molt han a cor aquest fet, deints expressament, per places e per cantons, que nostre procés e nostre dret és bo e clar, e no-s dubten per res de pecigament, si maldat no y corre, de part nostra (AMV, LM 6, f. 279v). 
en son dret e justícia, de la qual és tengut retre raó e compte a Déu. ${ }^{36}$ Era, justamente, lo que al rey, sometido a la presión de las cortes de Zaragoza, no le interesaba hacer entonces.

\section{Las negociaciones secretas del obispo Llupià (1400)}

A mediados de enero de 1400 consta la presencia en Zaragoza de missatgers valencianos, que fueron objeto de un bon e graciós acolliment por parte del rey y del obispo Llupià. ${ }^{37}$ La misión debió durar en torno a un mes, pues estaban de vuelta poco antes del 12 de febrero. ${ }^{38}$ No debieron tratar un asunto tan sensible como el de Chelva, que podía entorpecer la relación de la corona con los aragoneses. Pero el Humano, consciente de la necesidad de abordarlo, lo puso en manos de Llupià, quien envió a los ediles una epístola que les fue entregada el 27 de enero por Artés y el batle general Pujada. ${ }^{39}$ La respuesta al obispo, de la misma fecha, constituye otro documento revelador; ${ }^{40}$ se le hizo llegar en secreto para que él a su vez la hiciera llegar, también en pregon secret, al rey. Tanta cautela obedecía, según indicaban en el post scriptum, a la delicada situación en que se encontraba el monarca, condicionado por las cortes aragonesas en curso, donde García Fernández de Heredia, arzobispo de Zaragoza (1383-1411), actuaba como aliado del vizconde de Vilanova: certs som e és massa notori que tot aquest tracte e enburlament de la cort d'Aragó fan principalment l'archabisbe e sos adherents per sol esguart d'aquell e en favor del vezcomte, en no poch destrich e destorb dels affers del senyor rey, $e$ contra dret e justícia.

En la misiva decían que, tras recibirse el beneplácito del rey, el consell general había sido convocado para estudiar su propuesta, previo juramento de

36 AMV, LM 6, f. 279v (1400, enero, 14).

37 AMV, LM 6, ff. 280v-281r (1400, enero, 14).

38 Fecha de una misiva de agradecimiento a Guillem Ponç, secretario del rey: Jassia en moltes maneres fos cert e clar a nosaltres de vostra cordial affecció e bo e prest espatxament que tots temps hagués e havets e fets als affers d'aquesta ciutat e nostres, però, ara pus singularment e pus expressa som d'açò certifficats per los honrats missatgers nostres, venguts pochs dies ha de cort del senyor rey, los quals altament e be se'n són ab nosaltres raonats, e senyaladament e derrera l'onrat En Pere Gençor, I d'ells, vengut derrerament ab vostra special letra. On, sènyer, regraciants molt les dites coses a vostra saviea, pregam aquella a cautela de bona continuació. E pus ara no dë̈m, axí com no cal a sàvia testa, mas de tot ço que us sia plaïble metets-nos a prova d'amprament e veurets, Déu ajudant, com les obres seran conformes ab les paraules (AMV, LM 6, ff. 304v-305r; 1400, febrero, 12).

39 AMV, $L M$ 6, f. 291r.

40 Publicada en el apéndice: doc. núm. 7. 
tots e de cascun dels consellers de tenir-ho secret. Artés y Pujada se presentaron ante la asamblea, a la que informaron ampliamente e instaron a aceptar lo que el soberano pedía. Aunque no se da cuenta de ello de manera directa, todo apunta a que el Humano prometía declarar nulo, cuando estuviera fuera de Aragón, el proceso del justicia contra Valencia, a cambio de la devolución de Chelva al vizconde. Cuando salieron los comisionados se abrió el debate en el pleno de la institución municipal, cuyos miembros, uno a uno, hubieron de exponer su parecer: tots e sengles del dit consell, singularment e per orde, dixeren lurs vots ab diverses e moltes raons pro e contra a lur liberal voler. De los cuatro puntos sobre los que tuvieron que pronunciarse, el primero también el principal - era si consideraban suficientes las garantías que daba la corona de cumplir lo prometido. Y la respuesta de los consellers fue que dudaban de que el monarca pudiera llevar a buen término la promesa de llamar desde Cataluña al justicia de Aragón y declarar nulo el proceso por no ser juez competente, puesto que el magistrado, que no consideraba al soberano juez suyo, no se sentiría obligado a comparecer: lo justícia d'Aragó tots temps al·legaria que la sentència no li poria noure com lo senyor rey, segons ell aferma, no sia son jutge, e ell no sia tengut comparer denant lo dit senyor. Además, cuando en el futuro Valencia mostrase la sentencia real sobre el caso de Chelva, aquél siempre podría alegar que su propósito se habría cumplido de facto, ya que el señorío había vuelto a ser del vizconde: que de fet hauria haüt propòsit de sa intenció per ço com lo vezcomte hauria recobrat Xelva. Por otro lado, en caso de que el justicia decidiera comparecer ante el rey, podría presentar alegaciones que irían alargando el proceso y romandríem en aquest endemig despullats de nostra justícia. Afirmaban no dudar de la sinceridad de las promesas de don Martín, pero estaban seguros de que la preeminencia real y los privilegios de la ciudad no quedarían restablecidos hasta que aquél, appellat lo justícia d'Aragó e nosaltres, declarase nulo el proceso incoado por el primero y ordenase la devolución de lo incautado en Zaragoza a los habitantes de la ciudad. Esto último ya se habría conseguido - aseguraban - si ellos hubiesen respondido con dureza y contundencia, lo que hasta ahora habían evitado para no perjudicar al soberano: per no donar-li destorb en sos feyts.

Sobre el punto segundo - que la reina fuese la ejecutora del acuerdo entre Martín I y Valencia - no podía haber respuesta, al haber sido negativa la que dieron al primero los munícipes, quienes insistían en que lo que pedía la ciudad era cosa justa e honesta e digna de exaudició, és saber, justícia, por lo que no podía recibir denegació, dilació ne altre embargament. 
Se trató en tercer lugar la posible responsabilidad de la ciudad de Valencia si se prolongaba aún más la estancia del rey en Zaragoza, de donde debería de salir cuanto antes por causa de su enfermedad. Los consellers respondieron con una frase bien elocuente: estaban tan libres de culpa como un santo del pecado: tan quitis com fos haüt sant de peccat. Las cortes aragonesas eran las causantes de tan larga permanencia por haberse involucrado en un asunto que no les concernía, ya que Chelva era del reino de Valencia y el afectado un particular que no había recibido agravio alguno del rey ni de sus oficiales: ¿què s'atany la cort d'Aragó ab lo fet de Xelva, qui és d'aquest regne e de persona singular, en lo qual no ha greuge del senyor rey ne de official seu? Consideraban inadmisible que los aragoneses condicionaran la aprobación del donativo a que la corona dictara orden — dejando al margen todo proceso judicial- de desposeer a Valencia de Chelva y entregarla al vizconde: Mas dir que daran al senyor rey certa quantitat de moneda si, sens procés e sentència e sens tota coneguda de dret, contra tota ley divinal e humanal, lo senyor rey tol a nosaltres Xelva e la do al vezcomte, del qual, per sa uberta colpa e resistència, e ab procés tan solemne e tan justifficat, la ciutat la hagué e la ha tenguda e té pacífficament e ab just títol, no és àls dir o demanar sinó que·l senyor rey nos vena justícia per diners. Y aún más inaceptable resultaba ese proceder si se tenía en cuenta que el propio interesado y sus partidarios controlaban las cortes: esguardan que $l$ ls tractadors de la dita cort son lo vezcomte mateix, nostre adversari, e sos principals fautors. Los aragoneses eran, por tanto, los únicos responsables de la larga estancia de Martín el Humano en Zaragoza. Las posibles consecuencias negativas de ello no podían recaer sobre Valencia: E si lo justícia d'Aragó e la cort, per esforçar injustícia, fan estar aquí lo senyor rey, malalt e ab perill de sa persona e en gran dan de tots sos regnes e terres, les quals no pot visitar, ¿quin mal hi merim nosaltres, qui solament demanam e defenem justícia, de la qual ja en lo començament de la cort d'Aragó per nostres missatgers lo dit senyor fon supplicat?

La entrega voluntaria del señorío al rey por parte de Valencia, para que él lo entregara a la vez al vizconde - cuarta y última propuesta -, supondría, a juicio de los ediles, poner en peligro la supervivencia misma de la ciudad, que, como cualquier otra, se hundiría irremediablemente si no defendía sus libertades frente a los poderosos, barons o ciutadans o altres grans hòmens, que intentaran mermarlas. Se habían hecho eco los consellers de la arrogancia del noble y personas de su entorno, que habrían alardeado de que Chelva volvería a sus manos sin coste alguno. Una actitud provocadora y un motivo más para 
hacer imposible el cumplimiento de tan jactanciosa predicción: car par que ara.s vulla verificar ço que.l vezcomte e altres parents e amichs seus en temps passat han dit, ço és, que tantes maneres s'i assajarien que, per un cap o per altre, ell cobraria Xelva sens cost. No serà veritat, si Déus ho vol.

Pasados unos días llegaba a Valencia la respuesta del rey a la negativa del consell. El 9 de febrero, los jurats informaban a sus colegas misser Guillem Çaera y Joan de Fluvià, ausentes de la ciudad, de que Ramon Civeller, escrivà de ració, había llegado con cartas sobre el asunto, y que esperaba la contestación para entregarla a su retorno, por lo que les pedían que volvieran de inmediato, com en açò vaja tant com sabets. ${ }^{41}$ No conocemos la epístola del Humano, pero sabemos que contenía palabras duras contra el gobierno municipal. Efectivamente, el 12 de febrero, en carta a Llupià, los ediles se quejaban d'alcunes paraules carregoses per lo fet de Xelva y de los reproches de la misiva real, injustos por cuanto ellos no eran responsables de su larga permanencia en Zaragoza, estando enfermo, sino las maniobras dilatorias y de presión de las cortes aragonesas: Com sia cert e ubert a tot lo món que la raó de la sua estada e accidents fo e és per causa o fets de la cort d'Aragó, o, pus verament, d'alcuns singulars magnats d'aquella qui, ab nostra minva e ab ço del nostre, volrien enrequir lo vezcomte de Mançanera e fer do al senyor rey. Se lamentaban de los perjuicios que les estaba causando el justicia de Aragón y se reafirmaban en su intransigencia en lo relativo a Chelva: nosaltres no podem ne devem dar ne darem loch, per la vida, a algú dels partits moguts en delliurar Xelva al senyor rey. Pedían al prelado que hiciera comprender al rey que su respuesta no podía ser otra, y que debía dirigir los reproches a los verdaderos culpables de la situación, no a ellos: que cessen d'ací avant los dits càrrechs e l'escriure d'aquesta matèria, e dar los dits càrrechs a qui.ls ha e no a nosaltres. ${ }^{42}$

Disgustado por la negativa del consell a poner en sus manos el valle de Chelva - paso previo para su devolución-, Martín I presentó una segunda propuesta: que la ciudad le vendiera el señorío. Y la respuesta fue otra negativa, más contundente aún a juzgar por lo que los jurats comunicaron el 13 de febrero a los justicias, jurados, alamines, ancianos y habitantes del señorío: $E$ veén que que (sic) no li n'havem volgut complaure tro ací per aquelles maneres que ell volia, ara, per conclusió sua, nos ha tramés I missatger seu appe-

41 AMV, $L M$ 6, f. 296r-v.

42 AMV, LM 6, ff. 303r-304r. 
llat En Ramon Fiveller, pregan a nosaltres e al consell que li féssem venda de Xelva. A la qual venda ne lo dit ne lo dit (sic) consell ne nosaltres no havem volgut donar ne dariem loch, ans li havem rasament denegat fer aquella, dients que la ciutat no se'n desexiria per quants diners ha en lo món, ne darà jamés loch que.l dit mossén Pere Ladró cobre aquella. ${ }^{43}$

La tensión entre el rey y la ciudad convertía al obispo Llupià, en el que ambos parecían confiar, en hombre clave. El 12 de febrero, los jurats redactaron dos epístolas, una para el rey y otra, de carácter muy secreto, para él. En aquélla, por cautela, silenciaban cosas que no debían de trascender, y que sî figuraban en la segunda: ${ }^{44}$ En l'altra letra, sots data d'aquesta, que a vostra senyoria ara trametem, havem callat scientment ço que dejús en la present és contengut, com requira pregon secret e no seria raó que.s mostràs en l'altra letra, la qual de necessitat és mostradora. Lo que tan misteriosamente notificaban era un relato de lo sucedido: cuando Ramon Fiveller les expuso la petición del rey, los ediles se reunieron en consell de cambra y acordaron remitir la propuesta al consell general, donde, sens tota discrepància, fo concordat que no.s podia ni devia donar loch a les coses per lo dit En Ramon proposades e per lo senyor rey e per vós, senyor, scrites. Siguen diciendo los jurats que el día anterior había llegado de la corte Pere Gençor, missatger, que se reunió con ellos y con los abogados, el síndico y el escribano, a quienes, tras prestar uno por uno juramento de guardar secreto, mostró una credencial del obispo y comunicó la respuesta de éste - y de su hermano, mossén Ramon de Llupià-, a lo que con suma reserva habían propuesto los regidores en la última misiva per final resposta del fet de Xelva. Aludía a la carta secreta de los ediles, respondida ahora secretamente por dos influyentes hombres próximos al Humano. Ambos se ofrecían a dar respaldo a la postura de aquéllos, que no ocultan su entusiasmo: amdós hauriets sobre aquell aempre feta tal resposta que pus alta ne pus valerosa no's pogra dir ne fer de pare, de frare, de fill o d'altre qualsevol acostat grau de parentesch ne de dilecció a sos semblants. En bona fe, senyor, d'açò haguem tan sobirà plaer que a alcuns ne rodaren los ulls en aygua de cordial amor. El mensaje de los Llupià suscitó mayor contento aún cuando Gençor informó de la intervención del prelado en el consejo real cuando, al darse a conocer la respuesta negativa de la ciudad a lo solicitado por el monarca, se alzaron voces que le pidieron proceder contra Valencia; 
el obispo se erigió entonces en defensor del gobierno de la capital: vós [...] hauríets dit tot clar al senyor rey que fos sa mercé no apparellar-vos en res que fos contra nosaltres, car no ho poria sofrir vostre paternal cor, e altres mellors paraules. El consejo real habría acordado finalmente que si el soberano no podía obtener de los aragoneses el donativo, partiese hacia Cataluña, a los baños de Caldes, tal como le aconsejaban los médicos, e que no.s parlàs pus del fet de Xelva. Era lo que deseaban los regidores de Valencia.

Las prórrogas dilatorias de las sesiones de las cortes de Zaragoza se habían ido sucediendo «de forma casi interminable» hasta entonces. Estaba ya muy próximo el fin de la larga estancia en Aragón del rey, motivada por la resistencia de aquella asamblea a satisfacer sus demandas económicas sin antes dejar zanjada la cuestión de Chelva de manera favorable a don Pedro Ladrón y al justicia ${ }^{45}$ En marzo de 1400, el mes anterior al de la partida del monarca a Cataluña, se puso fin a la inactividad parlamentaria y se acordó que cuatro procuradores nombrados por los brazos investigaran los actos del justicia y sus oficiales en relación con la denuncia del vizconde de Vilanova. El día 26, la comisión declaró que todas las actuaciones habían sido correctas, por lo que no recaía sobre ellos ningún tipo de culpa (Navarro, ed. 2008, vol. 1: XVIIXVIII). También las confiscaciones de bienes de valencianos, incluidas las de los cofres de los enviados a la coronación, fueron consideradas lícitas por las cortes. El monarca hubo de aceptarlo, resignadamente según Zurita: «y aunque el rey que de su condición era de gran benignidad se sintió dello gravemente, pero en las cortes fue aquello aprobado y se dio el proceso por bueno; y como el mismo justicia dice, el vizconde fue defendido en la libertad del reino» (Zurita, X, 70, vol. IV: 853). Es posible que, además, antes de partir, don Martín se comprometiera verbalmente a devolver la baronía al vizconde en un futuro próximo, según veremos más adelante. Todo apunta a que se buscaron fórmulas para poner fin a la larga parálisis de las cortes antes de que el soberano emprendiese la marcha. Pero la crisis no quedó resuelta. Valencia seguía poseyendo Chelva y sus regidores se mantenían inflexibles en lo tocante a la jurisdicción del justicia aragonés en el reino. Además, la querella presentada por la ciudad contra el dignatario ante la justicia real había de ser dirimida por ésta mediante sentencia.

45 Es evidente la desorientación de Tasis cuando escribó: «L'estada del rei a Saragossa pogué donar satisfacció complerta als aragonesos, puix que va tenir-hi la seva residència sense gairebé cap interrupció del 7 d'octubre del 1397, al 10 d'abril del 1400» (Tasis, 1957: 204). 


\section{Negociaciones fuera de Aragón}

El rey se encontraba aún en Zaragoza el 7 de abril de 1400. El 11 estaba en Mequinenza. Una vez en Cataluña, se encaminó a la Garriga para tomar los baños que aconsejaban sus médicos, siguiendo la ruta de Tarragona, Vilafranca y Barcelona (Girona, 1916: 73-74). El 21, desde Valencia, los jurados intentaban contactar con el abogado barcelonés Guillem de Vallseca -el mismo que, años más tarde, votaría en Caspe a favor del conde de Urgell-, convencidos de que el Humano haría comprecer ante sí, en el principado, a las partes en litigio para impartir justicia: Nosaltres havem haüd cert sentiment que $\cdot$ l senyor rey, aprés que sia en Barchinona, o per ventura abans, pus és en Cathalunya, appellarà aquesta ciutat denant si per lo fet del debat que és entre Aragó e València per lo fet de Xelva, e axí mateix los d'Aragó. E jassia nosaltres, ajudant nostre senyor Déu, hi entenam trametre persones valeroses e de aprovada sciència per defendre nostre dret e justícia, emperò, per moltes rahons nos és expedient de procurar aquí alcun solemne doctor qui en nostra favor, com a advocat, ensemps ab los nostres, rahone lo fet e la justícia de la ciutat; e, entre'ls altres, nos occorre e volríem haver, si porem, l'onorable micer Guillem de Vallsecha. ${ }^{46}$

Los ediles esperaban la pronta celebración del juicio. El 9 de abril, desde Zaragoza, el obispo Llupià, les había informado por carta de la manera e finament de les corts dels aragoneses y de lo que el rey, personalmente, le había encomendado que les transmitiese: de ço que per lo senyor rey és estat dit a vós, senyor, e per vós, senyor, a nosaltres, del procés faedor a instància del procurador fiscal del senyor rey en lo fet del justícia d'Aragó contra aquesta ciutat per raó del fet de Xelva. Pese a no indicarlo de manera explícita, todo apunta a que se había decidido la comparecencia de los litigantes en Cataluña. Los jurats solicitaban por ello - en carta de respuesta, fechada el 10 de mayola intervención de Llupià para que se llevara a cabo: façats ab lo senyor rey que, a instància de son procurador fiscal, lo dit senyor appelle lo dit justícia

46 Es el comienzo de la carta al molt honorable e molt savi En Guillem de Fenollet, en Barchinona, a quien piden que de nostra part amprets lo dit micer Guillem, pregan-lo que a ell plàcia reebre nostra advocació y que a ell plàcia tenir les dites coses en secret tro lo temps e cas o requira. Redactaron asimismo una misiva dirigida al molt honorable e molt savi doctor micer Guillem de Vallsecha, en Barchinona, para que diera crédito a lo que en nombre de la ciudad le dijera Fenollet, quien al entregársela habría de pedirle discreción: Liurats-li la letra e explicats-li la creença en la forma damunt recitada, servan-li maneres, e en aquell secret que de vostra acostumada bondat e saviea se pertany e de vós molt confiam (AMV, LM 6, f. 341r-v). 
d'Aragó e nosaltres en Cathalunya per finir la qüestió que és entre aquell e nosaltres, per tal que vós, senyor, present e endreçant, lo senyor rey per justícia descàrrech si mateix e ses preheminències e superioritats, e per consegüent nosaltres, del dit justícia d'Aragó e de sos processes e enantaments. ${ }^{47}$

El 26 del mismo mes, el consell general de Valencia, previo juramento de guardar secreto - per orde de tenir-ho secret- de la materia que habían de abordar, acordaba el envío de missatgers a Barcelona. ${ }^{48}$ El sigilo obedecía a que la comparecencia de esa delegación no había sido requerida aún formalmente. Cinco días antes, desde la capital catalana, Llupià comunicó que el rey le había asegurado en privado que haría comparecer ante él a las dos partes en litigio, por medio del procurador fiscal, per finar lo debat que és entre lo dit justícia e aquesta ciutat per lo fet de Xelva. De ahí que el consell general nombrara de inmediato missatgers, pero ocultando el motivo. Ahora solicitaban del obispo que actuara para que, en cumplimiento de lo prometido, el procurador fiscal dirigiera cartas a la ciudad y al justicia para que comparecieran ${ }^{49}$ Francesc de Fluvià, uno de los embajadores valencianos, que ya se encontraba en Barcelona cuando fue nombrado miembro de la delegación, habría de entregar la misiva al obispo per impetrar haver e trametre prestament e tantost letres reyals citatòries al justícia d'Aragó e a nosaltres per lo fet de Xelva; pero lo había de hacer tant secretament e tan cuberta que hom nat ultra ell no sàpia ne senta que res hic proceeix de vós ne de nosaltres, mas de propri motui del senyor rey. ${ }^{50}$ Llupià, valedor de la ciudad y hombre de confianza del soberano, informaba en secreto a los jurados de las promesas de éste. E, igualmente en secreto, los jurados instaban al prelado a pedir a Martín I que las cumpliese.

A comienzos de junio eran expedidas por el gobierno municipal credenciales para mossén Pere Calderó, micer Guillem Çaera e En Francesch de Flu-

47 AMV, LM 6, ff. 352r-353r (1400, mayo, 10).

48 AMV, $L M$ 6, ff. 360v-361v (1400, mayo, 26).

49 Vostra letra, data en Barchinona a XXI del present mes, havén en substància que, de fet que·l senyor rey sia en Barchinona, segons per aquell ne sòts estat certifficat, farà mercé en exequció que lo justícia d'Aragó e nosaltres siam appellats denant lo dit senyor en Cathalunya a instància de son procurador fiscal per finar lo debat que és entre lo dit justícia e aquesta ciutat per lo fet de Xelva, reebem divenres a XXVIII del present mes. [...] hauríem en plaer que vós, senyor, féssets per manera que, ans que nostres missatgers fossen ab lo senyor rey, on, Déu volent, seran dins breus dies, lo dit senyor, per sa letra, a instància de son procurador fiscal, appellàs lo dit justícia d'Aragó e nosaltres, e se'n faés presentació d'aytal letra a nosaltres, si-s vol ab carta pública (AMV, LM 6, ff. 365v-366r; 1400, mayo, 31).

50 AMV, LM 6, f. 366r (1400, mayo, 31). 
vià, nostres missatgers, los quals a la presència personal de vostra senyoria trametem de present per affers molt ardues d'aquesta vostra ciutat. ${ }^{51}$ Consta que trataron, entre otros asuntos, lo fet del justícia d'Aragó, y que lo abordaron desde una perspectiva jurídica, lo que explica la presencia en la delegación del Guillem Çaera, jurista que poseía en su estudio de Valencia un volumen con los fueros aragoneses y otros documentos importantes en relación con el caso, cuya búsqueda y envío a Barcelona pidió a los jurats. ${ }^{52}$ Pudo tratarse de la ansiada comparecencia de la ciudad ante la justicia real, que no dictó sentencia de inmediato, sino cuatro años más tarde.

\section{Martín el Humano en el reino de Valencia (1401-1403)}

El 19 de mayo de 1401, Martín I embarcaba en Barcelona y ponía rumbo a Valencia. Su entrada en la capital del reino no fue posible hasta abril del año siguiente. Una epidemia de peste fue la causa del retraso. Por la misma razón, las cortes valencianas, convocadas en julio de 1401, tuvieron que celebrar sus sesiones primero en Segorbe, luego en Castelló y finalmente en Valencia, donde fueron licenciadas a finales de diciembre de 1403 (Danvila, 1905: 332-334; Tasis, 1957: 201-212). La vieja querella del fuero, reavivada los años anteriores, había de aflorar en el curso de la asamblea. En octubre de 1401, algunos miembros del brazo militar qui afermaven en lus lochs dins regne de València

51 AMV, LM 6, f. 367v (1400, junio, 4). También pedían apoyo a la reina en otra credencial del mismo día: On, senyora, com de la vostra special ajuda nosaltres façam singular e gran compte, e, ab veritat, a sana consideració los dits affers esguarden no tant solament nostra neccessitat e utilitat, ans encara stabilitat de la corona reyal e bé de la sua molt excel-lent persona, la qual és transcendentment cara a vós, senyora, e a tota la sua cosa pública... (ibid., ff. 367v-368r). Y a Llupià: No calria, ans par cosa supèrflua, recomanar en special a vós, molt reverent pare e senyor, nostres missatgers o affers, car vostra liberal ardor hi és ja tant habituada que en propri li és tornat, no menys que al pare natural la prosperitat de son fill; mas, per no prejudicar a bona costum, comparada a ley universal, recomanam, senyor, a sobreabundant cautela, a la vostra paternal gràcia e ajuda.... (ibid., f. 368r).

52 El 25 de junio, en carta a los missatgers, escribían: Per haver e trametre ço que demanats necessari al fet del dit justícia, trametem nostre síndich al estudi de vós, micer Guillem, e, jassia trobàs e portàs los vostres furs d'Aragó, però hanc no poch trobar lo full de paper que deïts, no contrastant que.l cercàs per tot diligentment. Havem oppinió que per ben estojar, l'ajats mès dins qualque clau o loch secret. E, veents que de vostre studi no podíem haver altre recapte, manam cercar per En Vilalba son archiu e los studis d'alcuns dels advocats passats. E jassia hi sien estats trobats alcuns qüerns, però, no faents per la matèria, almenys profitosament. E per ço no us podem trametre ne us trametem sinó tantsolament los dits furs per lo portador de la present, apparellats de trametre si més trobarem. E vós, si us plaurà, pensats e recordats de loch on lo dit full o altra scriptura d'aquest material hajats estojat, e rescrivitsnos de ço que recordar vos hen porà e us parrà. E tantost fer-hi hem ço que en nosaltres sia (AMV, LM 7 , f. $5 \mathrm{v}-6 \mathrm{r})$. 
usar fur de Aragó, exigieron salvaguardar su vigencia, cualesquiera que fuesen las leyes o medidas que se aprobaran. Y el brazo real, capitaneado por Valencia, refutó tal pretensión: contradient al protest feyt sobre la observança de furs de Aragó en alguns lochs de regne de València, dien que lo senyor rey En Jacme, attavi vostre, ab voler e consentiment de tots los braços, ecclesiàstich, militar e de ciutats [e] viles reals de regne de València, statuí e ordenà que en tot lo dit regne fos servat fur de València e que altre fur no y fos servat. Consideraban inaceptable la coexistencia de los dos ordenamientos jurídicos en el reino, donde no podía regir más norma que los furs de Valencia, jatsia alguns, per si matex e no degudament [...], en alguns lochs del dit regne servasen fur de Aragó. Para los patricios de la ciudad era una anomalía la vigencia del derecho aragonés, aunque hubieran de aceptarlo de facto. Ellos mismos, principales enemigos de la dualidad foral, tenían que aplicar el fuero de Aragón en los lugares que se regían por él - es el caso de Chelva-, cuando Valencia los poseía (Rubio, 2012, vol. 1: 151-152 y 168-177).

La disputa dialéctica se venía produciendo casi como un rito en las cortes valencianas, siempre en idénticos términos, desde tiempo atrás. También la respuesta de los monarcas, ambigua y dilatoria, era la misma. Y se mantenía sin alteración el statu quo. En esta ocasión, sin embargo, el rey Martín, consciente tal vez de las graves consecuencias que podría tener el reconocimiento de la autoridad del justicia de Aragón en el reino de Valencia, sería contundente en su pronunciamiento al respecto. En la primavera de 1403, los síndicos de la capital se habían quejado de la injerencia del magistrado en el caso de Chelva y solicitaron la anulación del proceso por él iniciado, com lo dit justícia de Aragó no haja alcuna conexença ni juredicció en los fets qui-s fan e.s sdevenen dins vostre regne. Considerando inaceptable que las cortes aragonesas hubieran arrancado la promesa de restituir el valle de Chelva al vizconde, exigían ahora al rey: no enantarets ni farets alcun procehiment contra la dita ciutat, ans mantendrets e defendrets aquella en sos drets e libertats. ${ }^{53}$ Las circunstancias habían cambiado. La presión sobre el monarca venía ahora de las cortes valencianas. Y daría fruto en septiembre.

En efecto, la denuncia contra el justicia que presentaron al Humano decía: com lo justícia d'Aragó, en gran menyspreu e deservey de vostra real corona e de les preminències e supremitats que vós, senyor, havets en regne de València, e en gran dan e prejuhi de les libertats e franquees e drets de la dita ciu- 
tat, haja assajat de fet, com de dret no pogués, fer procés e diverses enantaments contra justícia, jurats e alcuns altres ciutadans de la dita ciutat, per rahó de just e legítim procés e enantaments que los dits jurats feren contra lo noble mossèn Pere Ladró, vescomte de Vilanova, e muller de aquell, de la Vall de Xelva; ço que fer no ha pogut, com lo justícia d'Aragó no haja alcuna conexença ni juredictió en los fets que s fan e.s sdevenen dins vostre regne de València. Y el soberano, ad postulationem totius curie, revocó los procesos incoados por el dignatario aragonés super facto de Xelva, estableciendo en su sentencia del 28 de septiembre de 1408, de manera nítida, que la jurisdicción de aquél terminaba allí donde comenzaba el territorio valenciano: Lo justícia d'Aragó ha sa juredictió limitada per territori, ço és, per e dins lo regne d'Aragó, e no pot conèxer ni pertany a sa juredictió acte, causa, procés o fet actitat, fet o procehit fora l dit regne (Colón y García, eds. 2007, vol. I: 225; Gual, 1947-1948: 280).

Quedaba así resuelto y finalizado el asunto de Chelva, pero sólo en el ámbito jurídico-político del reino de Valencia. Seguía pendiente de sentencia la querella contra el justicia que la ciudad había presentado años atrás ante la jurisdicción real. El momento de pronunciarla llegó en 1404, en territorio de Cataluña. En los meses de junio y julio de ese año se encontraba en Tortosa el subsíndico de la ciudad, el notario Pere Miró, en cuya correspondencia con los jurats se indica que el rey había resuelto lo fet del justícia d'Aragó al determinar que el juez competente en la causa era él mismo, no el magistrado aragonés. ${ }^{54}$ Como es obvio, los regidores valencianos se mostraron interesados por ese pronunciamiento, dado en Tortosa, ${ }^{55}$ y pidieron a Miró que, antes de retornar a Valencia, consiguiera allí una copia íntegra del procés que s'és fet sobre lo fet del justícia d'Aragó, a fin de que quedara constancia de ello a perpetuidad: en manera que faça fe «in eternum». ${ }^{56} \mathrm{En}$ su vertiente judicial, el caso de

54 ...trametem-vos la resposta de la citatòria del justícia d'Aragó... (AMV, LM 8, f. 60r; 1404, junio, 18); Lo tresorer del senyor rey tramet per lo present correu dues sentències, una interloqutòria, altra difinitiva, per lo fet del justícia d'Aragó; e deu esser la primera, segons nostres requestes, la interlocutòria, la qual se deu primerament pronunciada per lo senyor rey, en què lo senyor rey declara sí esser jutge competent e no lo justícia d'Aragó (ibid., ff. 64v-65r; 1404, julio, 14).

55 AMV, LM 8, f. 67v (1404, julio, 26): La sentència que s'és donada per lo senyor rey en Tortosa no.s pot traure en forma fins que siam certs del kalendari que comença lo procés del justícia d'Aragó, lo qual procés és comemorat per lo rey en la dita sentència; e là on deu esser lo kalendari, és hi jaquit espay. E com a present no ajam lo dit procés per ço com creem lo protonotari lo se n'ha portat, és acordat que trametam hun correu a Çaragosa, a $N$ Ferrando Salloça, que $\cdot$ s trameta lo dit kalendari; e de continent que haurem cobrat lo dit correu, farem metre la dita sentència en forma.

$56 \mathrm{AMV}, L M 8$, f. $67 \mathrm{v}$. 
Chelva había terminado, según se indica también en carta a la reina del 9 de agosto: puys lo fet de Xelva fos finat (Girona, 1916: 143). No obstante, aún quedaba por resolver el problema en su otra vertiente, la política. Había que encontrar una fórmula para que el señorío volviera manos de los Ladrón de Vilanova. Como así ocurrió, pues es bien sabido que siguieron poseyéndolo durante siglos.

\section{Retorno del señorío al vizconde y pervivencia del conflicto}

Cuando se promulgó la sentencia, favorable a Valencia, de la querella contra el justicia, la corona negociaba con representantes de la ciudad una fórmula para que el vizconde fuese restituido en la posesión del señorío. Se propuso a la ciudad la permuta de la baronía de Chelva por otra, la de Rebollet y Oliva, que el monarca compraría previamente, libre de todo tipo de deudas y pleitos, a Ramoneta y Gilabert de Centelles.$^{57}$ La transacción, probablemente relacionada con un enfrentamiento que se ha documentado por esas fechas entre este último y el rey (Sempere, 2014: 68), se vería facilitada gracias a un acuerdo entre el monarca y el baile general de Aragón, realizado en Maella, donde estuvieron reunidas las cortes aragonesas entre el 26 de julio y el 2 de agosto del mismo año de 1404 (Zurita, X, 79, vol. IV: 884). En virtud del dicho acuerdo, una vez acabado el proceso contra el justicia, las cortes harían efectiva la entrega a Martín I del donativo de sesenta mil florines, retenido hasta entonces. ${ }^{58}$ Pero algo impidió que lo pactado se hiciese realidad. Todo pareció desbaratarse, a juzgar por una carta a Maria de Luna, escrita a comienzos del mes de noviembre, en la que don Martín le informa de cómo, tras un debate en el seno del consejo real, había decidido apropiarse del señorío - pendre a nostra mà lo vall de Xelva - y ordenado al gobernador del reino de Valencia que ejecutase la orden: que anàs a la dita vall e prengués aquella a nostra mà. Como aún no lo había hecho, los diputados aragoneses seguían reteniendo los sesenta mil florines, con gran daño suyo, por lo que el soberano le había mandado de nuevo, bajo amenaza de penas graves, que la obedeciese. ${ }^{59}$

57 AMV, $L M 8$, f. 90r.

58 Carta a la reina, de 9 de agosto de 1404: ...certificam vos que stants en Maella ne parlam ab lo batle general d Arago que ell lo posas en segur e concordam e finam ab ell, que puys lo fet de Xelva fos finat, per lo qual passarien a nos los LX milia florins... (Girona, 1916: 143).

59 Per altres letres vos havem scrit notificants vos com nos havem deliberat ab nostre consell ací, de pendre a nostra ma lo vall de Xelva; e com manavem per altres letres nostres al governador d aquex regne 
La radical disposición de Martín I debió de provocar estupor entre los ediles valencianos, que unos días después, haciéndose eco de aquélla, se dirigieron al rey: De la vostra senyoria molt gran és, segons havem entés, emanada una letra reyal dreçada al governador de aquest regne, en la qual, entre les altres coses, li mana que's prenga lo riu e val de Xelva, sens alcun altre procés, mas de fet, ne sper alcun altre raonament. La corona había acordado desposeer a la ciudad del señorío de Chelva sin haber juicio ni sentencia, lo que consideraban un acto injusto, impropio de una dinastía como la catalanoaragonesa ${ }^{60} \mathrm{y}$ reiteraban su voluntad de hacer la permuta, que había sido propuesta - subrayaban - por iniciativa del monarca: volenters nos estariem e estarem de fer aquesta altra permutació de Xelva; e ço que s'i és fet, sabets, senyor, que s'és fet tot a vostre servey, no pas que nosaltres vos ho ajam cerquat ni mogut. Atribuían a intrigas de malos consejeros el fracaso del acuerdo -bé creem que ací influeixen mals parlaments e suggestions [...] de alcuns que meten tot lur saber e enginy en irritar vós, nostre rey príncep e senyor, contra aquesta ciutat, als quals, senyor, si fos vostra mercé, deuríets denegar audiència, cor ab tot lur ingeny s'esforcen metre torb en aquest contracte, $e$ sís farien en tot altre que s'ymaginas, per ço que lo finament de Xelva los sia exaquia, com ja no.ls ne reste altre a irritar vostra senyoria que a.questa ciutat, en la qual e tot son regne han sembrat pro mals e scàndels - y le pedían que ordenara al gobernador, por medio de otra epístola, paralizar la ejecución de la orden y no proceesqua o enante en lo dit fet.$^{61}$

Y así fue. Bernat Vidal, missatger de Valencia en la corte, había conseguido que quedara en suspenso, al tiempo que los patricios acordaban el envío de una solemne embajada al monarca, compuesta por un noble, un caballero, dos

de Valencia, que anas a la dita vall e prengues aquella a nostra ma. E segons vehem encara no $u$ ha fet, de que som fort meravellts, e lo dit governador $n$ es digne de gran reprehensio e castich; car tant com se triga pendre a nostra ma la dita vall, se retarda que nos no podem haver los LX milia florins, los quals los deputats del regne d Arago nos tenen empenyorats en gran dan nostre. Per que nos de present per nostres letres manam fort expressament sots grans forts penes al dit governador, que no curant de pretest ne $d$ altres coses repugnants a aço, vaja personalment e prengua la dita vall segons dit es (Girona, 1916: 151).

60 De què, senyor, som, e no sens gran raó, maravellats, car és a nosaltres cosa nova e inusitada lo primer procés de fet que hajam sabut e hoüt dir que proceís de la casa de Aragó, casa, senyor, e senyoria reyal, e en existència e en fama universal vulgada per tot lo món de justícia, egualtat e dretura. Senyor molt excel-lent, ¿ha u merescut per ventura aquesta ciutat que vós la delibertets e li façats tal procés que l la vostra casa no ha costumat fer encara a sos desleals? Sens hoir la ciutat en son dret o en sa justícia, li manats tolre la sua vall e riu de Xelva, pendent majorment ferma de dret, e lo procés de aquella no determenat per sentència o en altra manera (AMV, LM 8, f. 90r; 1404, noviembre, 22).

61 AMV, $L M 8$, f. 90r. 
doctores y dos ciudadanos, con el objetivo de disuadirlo. ${ }^{62}$ Sin éxito. Los regidores, en otra misiva a don Martín, señalaban que aquellos embajadores, tornats de la vostra cort, habían informado al consell de su negativa, y lamentaban de nuevo que el monarca hubiera dado una orden así sin sentencia judicial previa, que habría sido acatada en cualquier caso: e si aquesta ciutat per justícia deu perdre Xelva, és ne contenta; e si no, ço que és stat enantat sia reduït a justícia e dretura. Expresaban su parecer, contrario a la del soberano, que había sostenido ante los embajadores que el juicio había tenido ya lugar: de açò és stat fet ja juhí. También le recordaban cómo ellos, para complacerlo, habían aceptado el acuerdo de permutació, tractat ab vostra senyoria, de la dita vall e riu de Xelva ab la baronia de Oliva en la manera tractada, y que sólo habían mostrado su desacuerdo en la redacción de dos punts, dels quals era debat entre alcuns del consell de vós senyor e nosaltres. ${ }^{63}$

Pero el monarca, en un giro autoritario evidente, había tomado la decisión de privar a la ciudad del señorío, sin proceso alguno, por el mismo procedimiento militar que ella empleó. A finales de 1407, Guillem Ramon de Montcada, entonces gobernador del reino, fue el ejecutor de la orden.$^{64}$ Todo volvería a ser como antes de la intervención armada de 1395: don Pedro Ladrón tras el paréntesis iniciado entonces, fue de nuevo señor efectivo de Chelva. ${ }^{65} \mathrm{Y}$ la cuestión jurisdiccional, no resuelta, siguió causando enfrentamientos.

62 Aprés de açò, sènyer, havem haüda letra vostra ab translat d'una del senyor rey per la qual mana sobreseir en lo feyt de la occupació de Xelva, e havem haüd plaer del dit sobreseïment e de la vostra bona diligència. A major cautela, sobre açò, lo consell ha eleta solempna misatgeria al senyor e a la senyora reyna, de sis persones, com l'acte ho requira, ço és, un noble, un cavaller, dos doctors e dos ciutadans. Lo noble és mossén Pere de Muncada, lo cavaller mossén Luís de Castellví, los doctors micer Francesch Blanch, micer Anthoni de Alagó, los ciutadans vós e En Johan Torragrosa. E esperatslos aquí, cor, Déus volent, prestament seran ab vós. Tots nos ho han atorgat, exceptat que encara no havem parlat ab mossén Luís de Castellví, qui no és ací, mas havem-li escrit que vinga, e pensam que no.ns en dirà de no (AMV, LM 8, f. 94r-v; 1404, entre el 28 de noviembre y el 3 de diciembre).

63 AMV, $L M$ 8, ff. 133r-136r (1405, mayo, 12).

64 El 30 de marzo de 1408 comienza el volumen titulado Procés de la informació rebuda per los actes fets en Xelva per lo noble mossén Guillem Ramon de Moncada, governador de regne de València (AMV, Processos, vv-12). En las páginas iniciales queda constancia de que en las primeras semanas de diciembre de 1407 la ciudad de Valencia fue desposeída de la villa, castillo y lugares del valle de Chelva, mediante el uso de la fuerza, por el gobernador, al que se acusa de haber incautado los béns de la ciutat qui eren en los castells e vila de la dita vall, hoc e los béns de la vila, lochs e alqueries de la dita vall de Xelva, los quals béns són stats preses e occupats de fet e contra disposició de furs e privilegis del regne de València e de Aragó (ff. 1r-5r).

65 El 14 de enero de 1415, en las actas de las cortes valencianas, se lee: «...la vall e riu de Xelva e lochs de aquells [...], qui són del noble En Pere Ladró, vezcomte de Vilanova...» (AMV, Procesos de cortes, yy-6, f. 250r). En 1420 le había sucedido «lo noble en Ramon Ladró, vezcomte de Vilanova, senyor de la vila e vall de Xelva» (AMV, Claveria comuna, J-42, f. 2r; 1420, junio, 17). 
Una década después, cuando Chelva estaba en manos del vizconde, éste seguía considerando que la autoridad del justicia de Aragón se extendía hasta sus tierras. El 3 de marzo de 1416, los jurats, como jueces de los emprius, enviaron a ellas un verguer para realizar algunas confiscaciones. Al llegar a Domeño, lugar del valle de Chelva, se presentó el noble en actitud hostil, con unos doscientos hombres a caballo, moros y cristianos, y tuvo lugar un enfrentamiento verbal, durante el cual lo dit vezcomte li dix que com la terra fos aforada a fur d'Aragó e fos del governador d'Aragó, que la juredicció pertanyia al justícia d'Aragó e no pas als dits honorables jurats. El de Vilanova también se dirigió a hun hom qui era allí, nomenat lo procurador del dit governador d'Aragó, quien dijo al portero de los ediles que ell era procurador del dit governador d'Aragó, e com la terra era de aquell, que la ciutat de València no y havia que veure ne conéxer en res, com no y hagués alguna juredicció, e axí, que tantost lo dit verguer li buydàs la terra e li lexàs les penyores. Así pues, pese a la sentencia de Martín I del año 1403, el vizconde seguía planteando el conflicto jurisdiccional, con la argumentación de antaño: como en su señorío regía el código aragonés, qui és e fon primer que no lo dit fur de València, sólo reconocía la autoridad del justicia de Aragón, axí com a jutge superior qui és del dit fur d'Aragó.$^{66}$ La sentencia del Humano no había modificado la inflexible posición del noble acerca de la jurisdicción del justicia en sus territorios valencianos poblados por el fuero de Aragón.

En tiempos muy posteriores, en unas instrucciones dadas en 1482 por los jurats a Sancho Falcó, enviado a la corte de Fernando el Católico, el intrusismo institucional aragonés seguía presente en el horizonte de los valencianos: sab la majestat del senyor rey que los officials de Aragó volien metre les mans en los dits vezcondats e castells de aquell [regne de València] per sostenir-los a fur de Aragó e jutgar-los ells segons fur de Aragó ${ }^{67}$ Cuatro años más tarde, de nuevo elevaban sus quejas ante una posible acción, dirigida precisamente contra Chelva, del justicia: E al que's diu que lo justícia de Aragó ha fetes provisions e actes ab los quals se diu que deu venir lo vezcomte de Biota per pendre la possessió de Chelva, és cosa molt exorbitant e contra justícia que justícia de Aragó tingua poder e jurisdicció en aquest regne de València, car ja lo nomenar-se justícia de Aragó importa que fora lo regne no té poder algú. Açò ja és stat declarat per lo alt rey En Martí, e los officials preheminents de

66 AMV, Procesos, vv-14, ff. 28v-29r y 47v-48r. Vid. Rubio (2012, vol. 1: 180-181).

67 AMV, LM 30, f. 83r-v (1482, julio, 18). 
Aragó ne han vists moltes experiències.$^{68}$ Así pues, aunque desde 1403 Valencia disponía de un instrumento legal que negaba capacidad jurisdiccional al justicia de Aragón en el territorio valenciano, en la práctica siguió siendo imposible evitar su intromisión, con el conflicto consiguiente entre las oligarquías de ambos reinos.

\section{Una reflexión final}

En la raíz de todo ello estaba el dualismo foral, producto de circunstancias históricas que remontaban a la conquista del reino de Valencia. Un problema jurídicamente complejo, con derivaciones en los terrenos económico y político, que, pese a los avances en la territorialización de los furs de Jaime I a lo largo del siglo XIV, provocó periódicamente episodios como el estudiado. Aunque a veces ha sido la anécdota lo único recordado, sería un error considerarlos históricamente irrelevantes. Por un lado, porque ponen de relieve la fragilidad de las estructuras estatales de la Corona de Aragón, la escasa capacidad de la monarquía para resolver un litigio entre reinos; de ahí el recurso a una suerte de diplomacia secreta cuyo objetivo era sortear obstáculos mediante acuerdos y promesas verbales que mantenían inalterado el statu quo sin dar solución a los problemas de fondo. Por otro, por sus consecuencias manifiestamenrte negativas para la cohesión interna de la monarquía catalano-aragonesa. Los repetidos enfrentamientos producían un deterioro de las relaciones entre las oligarquías territoriales que ayuda a comprender el repliegue particularista progresivo de los reinos.

La voluntad de las clases rectoras aragonesas de que su derecho siguiera vigente en el reino de Valencia era tan firme como la de los patricios valencianos en proclamar los furs de Jaime I ley única y universal en él. Mayor grado de firmeza aún se advierte en la defensa y rechazo - respectivamente - de las intervenciones del justicia de Aragón en territorio valenciano, generadoras de tensiones políticas en las que se enarbolaban argumentos de cariz patriótico. Resulta patente la vertiente que podríamos denominar nacional en el planteamiento de la cuestión. El hecho de que el fuero de Aragón rigiese en una porción del reino tenía una dimensión no estrictamente jurídica, en tanto que

68 AMV, LM 31, f. 164r. Poco antes escribían: E en lo derrer capítol de la vostra letra nos significau que lo spectab [l] ve vezcomte de Biota no és aquí, ans se deÿa's devia venir en aquest regne ab provesions e actes del justícia de Aragó per haver Chelva, e que per vós los és stat respost (AMV, LM 31, f. 162v). 
afectaba a un símbolo colectivo de los valencianos, los fueros jaiminos. Y ello, al igual que el intrusismo del justicia aragonés, podía ser presentado por el patriciado de la capital como una suerte de agravio nacional, un atentado contra la independencia institucional del país. Indudablemente, era un arma eficaz para la defensa de intereses políticos y económicos.

En la documentación relativa a la confrontación suscitada a raíz de la toma de Chelva, desde el primer momento aflora la retórica identitaria. Ambos grupos dirigentes procuraron presentar la cuestión, no como una querella particular, sino entre colectividades nacionales. ${ }^{69}$ Pedro Ladrón, al plantear su privación del señorío como un agravio a las instituciones aragonesas, consiguió provocar el encono, la excitació dels aragoneses - contra los valencianos, obviamente- (Vidal, 1974: 152), expresión elocuente que figura más de una vez en los textos: És-nos estat dit ara, senyor, que l justícia o la part, per indignar los aragoneses, afferma que per part nostra li seria estada feta gran injúria [e] menyspreu, escribían los jurados en una misiva fechada el 12 de junio de 1398, en la que más adelante aseguran haber sabido que $l s$ dessús dits, per excitar los aragoneses, esforçen metre aquest fet en la cort d'Aragó. También habría llegado a sus oidos que las cortes aragonesas podrían dar respaldo a la opinió d'alcuns qui entenen que l dit justícia, ab les osts d'Aragó, poderosament deja venir a Xelva per haver aquella a sa mà, si porà, e si no, per damnejar a nosaltres o a coses nostres, lo que da pie a una respuesta efectista, también de tono combativo: com del tot los aragoneses volguessen venir [...], invocam sobre açò lo testimoni de Déu e del món, e, ab ajuda sua, per nostra defensió, entenem fer de manera que ells no's puxen jactar ne gaubar de lur errada.$^{70}$ La dimensión emocional reaparece con trazos claros el año siguiente, cuando los ediles acusan a don Pedro Ladrón, y a los aragoneses que lo apoyaban, de buscar la destrucción de Valencia: tot açò no seria àls sinó un bell engan del vezcomte e dels aragoneses de la sua favor, qui ab ço del nostre volrien fer servii al senyor rey; o no seria me [n]ys que ells dir al senyor rey: 'senyor, destrouits València, e dar-vos hem'. La qual cosa és de gran abhominació..$^{71}$

Unos meses más adelante, a mediados de diciembre, denunciaban la pretensión del justicia de Aragón de suplantar al monarca común como suprema

69 Sobre el sentimiento nacional aragonés vid. Sesma (1987 y 1988).

70 Doc. núm. 1 del apéndice.

71 Doc. núm. 4 del apéndice. 
autoridad judicial del reino: a desplaer de natura, vol e s'esforça esser nostre jutge, e pus subirà en aquest regne que $\cdot$ l senyor rey..$^{72}$ Palabras éstas en las que late un juicio negativo sobre la institución aragonesa. Algo parecido aflora en la valoración del ordenamiento jurídico aragonés, cuya naturaleza minaría la solidez de la monarquía y haría peligrar el principio de la igualdad entre los reinos. Recordaremos al respecto que, durante otro enfrentamiento que tuvo lugar ocho décadas después, en 1482, los jurats sostuvieron que los furs de Valencia respetaban la preeminencia de la monarquía, mientras que la legislación aragonesa la derogaba, y de ahí que los reyes hubieran ordenado siempre a sus oficiales que no observaran el fuero de Aragón en el reino de Valencia, ni siquiera en aquellos lugares que se regían por él. ${ }^{73}$ Por aquellas fechas, el vizcondado de Chelva había vuelto a ser el centro de un debate en el que los jurats nuevamente enarbolaron el sentimiento patrio al pedir que als officials de València e ciutat de Valencia no sia fet prejuhí en voler que stranger e aragonés tinga lo dit vezcondat, lo que no seria may comportat de home de regne de València tingués offici en regne de Aragó (Rubio, 2012: vol. 1, 193). Así como en Aragón no se admitía que un valenciano ocupase un cargo, no era aceptable que un aragonés rigiera un señorío valenciano. Un argumento revelador del triunfo del particularismo en la Corona de Aragón en los albores de la Edad Moderna.

\section{Documentos}

1398, junio, 12.- Valencia.

Los jurados de Valencia agradecen a Hug de Llupià, obispo de Tortosa, los favores que procura a la ciudad en la corte, le explican las razones de su rechazo a las pretensiones jurisdiccionales del justicia de Aragón en el reino de Valencia, motivadas por el asunto de Chelva, y le advierten del intento de involucrar en este problema a las cortes de Aragón.

-AMV, $L M$ 6, ff. 6v-8r.

$\mathrm{Al}$ molt reverent pare en Christ lo senyor bisbe de Tortosa.

72 Doc. núm. 6 del apéndice.

73 Decían: los quals furs de Aragó sab sa reyal majestat quant deroguen a ses reyals preheminències $e$ strenyen la potestat reyal, lo que és en contrari dels furs de València, qui són molt obedients a les reyals preeminències e no tolen la real potestat, per la qual rahó los reys passats han statuhit que los officials de aquest regne no serven los furs de Aragó a les terres de aquest regne encara que sien poblades a fur de Aragó (Rubio, 2012, vol. 1: 192). 
Molt reverent senyor: No·ns sentim bastants a vostra senyoria retre les gràcies e mercés que's mereix per tals e tants benifets que a tots jorns reebem de vostra molt reverent paternitat, senyaladament en pendre los affers nostres o de la ciutat, de paraula o per obra, axí com vostres propris, segons que·n som certificats de dia en dia. E per ço pregam a nostre senyor Déu, qui n'ha lo poder, que us ho retribuesca deçà e dellà, e do a nosaltres cas e loch de mostrar per obra nostra affecció en vostre servii e de al·leujar nosaltres de gran càrrech en que som per recepció dels dits benifets.

E, venints a spècie dels affers de Xelva, dels quals se fa festa e enferiment axí com si no n'hagués altres lo senyor rey e fossen fets a son dan, ço que és uberta error, com sien estats fets més per mantenir ses regalies e superioritat que per bé d'altri, per ço que la vostra senyoria sia certificada de nostra bona justícia, en dret e en fet, e-s puxa reposar en aquella, certificam la vostra senyoria de dues coses, entre les altres, ab proferta de tota prova.

La primera és que 1 procés fet contra Xelva per nostres precessors, ladonchs jurats d'aquesta ciutat e jutges ordinaris dels aemprius d'aquella, fo fet axí justament, raonable, madura, spaciosa e necessària, que esmena no pot haver, com sia tot fundat en gran e uberta culpa, fadiga e resistència de la part de Xelva, en expresses e clars furs e privilegis, e en sentències obtengudes en contradictori juhí, no solament en semblants cases, mas encara de Xelva matexa, e en ús e costum tots temps observats, segons que·s pot mostrar per lo dit procés e en altra manera.

La segona és que diverses e moltes vegades mossén lo governador d'aquest regne e los dits nostres precessors, per lurs letres, han dit e al·legat per veres e clares raons al justícia d'Aragó que ell no's podia ne pot entrametre, ne era ne és jutge d'aquest fet, no solament segons nostre fur e segons dret comú, ans encara segons lo fur d'Aragó mateix, offerints-se apparellats ells e nosaltres tot açò mostrar e averar, per los furs de cascun regne e per dret comú e per públichs actes e muniments e per vives raons, en col-lació havedora a les fites o mollons dels regnes o en covinent e comun loch, e, requerints e afrontants al dit justícia de venir a la dita col-lació ab sos savis e nós ab los nostres; la qual cosa lo dit justícia jamés no ha volgut fer, deint o al·legant que ell tenia loch cert de fer sos juhís, ço és, la ciutat de Çaragoça, e que si los dits governador e jurats volien res al·legar o mostrar, que anassen denant ell. La qual cosa, reverència de la vostra paternitat e benivolència dels dits justícia salves, era e és gran error, com, segons dret exprés e vulgat, si dos jutges contenen de juredicció, un d'aquells no deu ne és tengut adir la cadira de l'altre, ans faria a si minva e prejuhí, mas amdós deuen venir en comun loch a col·lació. E jamés lo dit justícia no ha volgut en açò averar, ans de fet fa ço que·s vol, no contrastant-li hajam escrit que·n pren gran càrrech volent dirimir aquest fet, no per dret, mas per força; hoc més, que cascuns missatgers que hajam trameses al senyor rey en Aragó per aquests e altres affers, lo dit justícia ha marchats e penyorats, faent pendre les cavalcadures, libres e robes lurs e de lur companya, contra privilegi de libertat e segurtat de missatgers, ço que hanc no fo fet en terres de tartres e de turchs ne d'altres.

És-nos estat dit ara, senyor, que·l justícia, o la part, per indignar los aragoneses, afferma que per part nostra li seria estada feta gran injúria [e] menyspreu en ço: que ell hauria tramés porter o commissari seu, ab scrivà e ab testimonis, a Xelva, per fer certs proceïments e que 1 lochtinent de procurador nostre de Xelva los hauria fets pendre e dites alcunes injurioses paraules e fetes alcunes conminacions. Sobre açò havem dites bones respostes. La primera, que, ab veritat, no's féu de nostre manament ne voler, ne·n sabíem res, ans, tantost com ho sentim, escrivim al dit 
El justicia de Aragón frente a la ciudad de Valencia. Un conflicto entre oligarquías territoriales...

lochtinent que·l soltàs e·ls lexàs anar ab tot ço del lur, segons féu. E la segona, que·l dit justícia, puys no volia venir a la dita col-lació ne en Xelva podia ne pot exercir juredicció, no y devia trametre los dessús dits, ne ells devien empendre tal anada, ne exercir jur[e]dicció que no·ls pertanyia, ans, com a usurpadors, eren dignes de major mal, e nosaltres, per benignitat, no curan de lur errada, los fem soltar. E fo a ells profitós, car mossén lo governador, quant ho sabé, dix e jurà que si enans ho hagués sabut, ell haguera tramés per ells e-ls haguera fet metre a la forcha per lur castich e exemple d'altres.

Encara·ns és estat dit que·ls dessús dits, per excitar los aragoneses, esforçen metre aquest fet en la cort d'Aragó, volents-ne fer acte o greuge de cort, ço que no és ne s'i acosta ne li attany res, com sia fet de part a part. Són altres que dien que més se fa per tal que tota la cort se concorde a la opinió d'alcuns qui entenen que 1 dit justícia, ab les osts d'Aragó, poderosament deja venir a Xelva per haver aquella a sa mà, si porà, e si no, per damnejar a nosaltres o a coses nostres. E bé que açò no's puxa acostar a nostra creença - per dues raons: la una car en la cort ha tantes e tan notables e sàvies persones de cascun braç, que bé sabran entendre que no és nostra la culpa e poran contrastar a les parcials affeccions; e l'altra, car no seria àls sinó voler torbar la cort, hoc e torbar aquesta santa armada, la qual és pròpria de nostre senyor Déu e toqua son fet e son servii, e no pensam que alcun christià de sana pensa vulla pendre tan gran càrrech en deservir de nostre senyor Déu e en dan e vituperi de tota christianitat, la qual en comú lo fet d'aquesta armada toqua no menys que nosaltres en singular-, emperò, senyor, com del tot los aragoneses volguessen venir, axí com dit és, e no sia pus en nosaltres, invocam sobre açò lo testimoni de Déu e del món, e, ab ajuda sua, per nostra defensió, entenem fer de manera que ells no·s puxen jactar ne gaubar de lur errada. E, puys aquest fet volen dirimir, no per dret, mas per força, sia nostre senyor Déu jutge entre ells e nosaltres, e ajut a la veritat e a la justícia, axí com fermament creem que farà, ja que ells entenen que·l senyor rey no se'n pot entrametre.

E vós, senyor, si plaer és vostre, continuan vostres bons principis fer-hi ets ço que és vostre. E pus no deïm, axí com no cal a sàvia testa, mas que conserve nostre senyor Déu a son servii vostra molt solemne persona en bona e longa sanitat e vida, e la faça prosperar segons sos bons desigs. E de totes coses que us sien plaïbles, senyor, podets aemprar nosaltres ab tota confiança. Scrita en València a XII de juny de l'any XCVIII.

Los jurats e consell de València, qui·s comanen en vostra gràcia.

2.

1398, julio, 24.- Valencia.

Los jurados de Valencia responden a Martín el Humano, que había pedido el envío de embajadores para tratar de la cuestión de Chelva, y exponen las razones de su radical oposición a reconocer autoridad jurisdiccional al justicia de Aragón en el reino de Valencia.

-AMV, LM 6, ff. 30v-31r.

A la molt alta majestat de nostre senyor lo rey.

Molt excel·lent senyor:

De la vostra magnificència, per mà de vostre feel secretari En Johan de Tudela, havem ara reebuda una letra continent creença per vós, senyor, a ell comesa envers nosaltres sobre los 
affers de Xelva, en virtut de la qual ell ha explicat a nosaltres en substància que a vós, senyor, plau bé de nosaltres trametre a vostra reyal presència, per los dits fets de Xelva, nostres missatgers, assegurats per vós, senyor, de tota marcha e represàlia del justícia d'Aragó. Responguem, senyor, tantost de paraula al dit vostre secretari e ara ab la present. A vós, senyor humilment responem que, com aquesta o semblant cosa fer no puxam sens general consell, e tan prestament no puxam aquell celebrar per absència d'alcuns notables hòmens, axí doctors com ciutadans, qui en los dits affers han tenguda la mà e hi saben molt, que nosaltres, haüts aquells, a cascun dels quals de lur presta venguda havem escrit, celebrarem consell e ab aquell acordarem e farem ço que Déu nos administrarà. Entre tant, senyor, consideran que·ls dits affers són sobres cars, com toquen pregonament interés e prejuhí no menys de vostra superioritat e regalia que de nostre dret, e que sens perdre temps podem e devem de ço qui-s segueix vostra senyoria informar e consultar secretament a aquella per la feeltat que li devem, notificam que, a tot nostre saber e entendre, proceir al present en missatgeria ne en compromés, ne en res àls d'aquests affers, estants en los térmens que huy són, és o seria capital prejuhí e irreparable dan a vós, senyor, e a nosaltres, almenys per tant car, sol per entrametre's de fet lo justícia d'Aragó de exercir sa juredicció fora sos límits d'Aragó en aquest regne, usurpa vostra juredicció, superioritat e regalia, e prejudica e plaga nosaltres en nostre dret; e d'aquén erra molt e massa, en la qual error està e perservera huy en dia, e té, en quant és en ell, vós, senyor, e nosaltres prejudicats. E que, estants axí, li sia consentit tracte de compromés ne d'altre acte, ne per açò feta missatgeria, no és àls sinó consentir-li sa usurpació e approvar-li sa error. Item, una de les coses com a pus cara, derrere la qual lo dit justícia e la part e lurs adherents són anats tro ací, és estada e és que d'aquest fet volguesse[n] en via judiciària o arbitrària o de col·lació se tractàs en Aragó, e·ns hen són estades fetes en temps passat alcunes profertes de favorable justícia a fi que una vegada nos poguessen tirar lla e que la juredicció del justícia a lur intenció fos approvada e perpetuada; e ells aquestes coses aytals solen fer continuar en los proceïments e actes de la cort del dit justícia, e per avant trahen-les a conseqüència en sos cases, e vé·ns ací, senyor, lo irreparable prejuhí. Item, diverses e moltes altres raons hi ha, longues per escriure, denotants incompetència de loch e altres prejuhís, les quals, senyor, fan duptar nosaltres de nostre desavantatge, e per consegüent, e més, del vostre, sab Déu, per nostra feeltat e naturalea. Però, senyor, com del tot a vostra senyoria plagués, la demanda [de] missatgeria, no contrastant ço que dit és, creem, senyor, que·l consell s'acordarà de fer aquella per vostra complacència e servii; mas de tant som certs, per los raonaments passats del dit consell, que tals missatgers no trametria ab alcun poder de comprometre estant vós, senyor, en Aragó. Tant se dupten de prejuhí. Ne aytanpoch trametria enaprés tal poder estant vós, senyor, e ells en Aragó, per aquell mateix dupte. Més avant, senyor, nos occorre altre dupte: si los dits missatgers van e estan aquí en la presència de vós, senyor, sens tal poder, mas solament per informar vostra senyoria de les raons perquè-l dit compromés no·s pot ne's deu fer, que alcuns de la cort d'Aragó no prenguen per açò punta pus fort o occasió de dar destorp a nostres affers, major que no han fet tro ací. Totes aquestes coses, senyor, cuytadament e secreta, a la vostra magnificència reyal anunciam, humilment a aquella supplicants que sia sa mercé, per aquella manera matexa, ço és, secretament e cuytada, obrir sobre açò, per sa letra, a nosaltres la sua voluntat e bona intenció. E mantenga nostre senyor Déu, etc. Scrita en València a XXIIII de juliol de l'any XCVIII.

Senyor, vostres humils vassalls e affectuoses servidors, qui, besants la terra denant vostres peus, se comanen en vostra gràcia e mercé, los jurats de València. 
El justicia de Aragón frente a la ciudad de Valencia. Un conflicto entre oligarquías territoriales...

3.

1399, marzo, 14.- Valencia.

Los jurats instan a Hug de Llupià, obispo de Valencia, a proteger en Zaragoza a los embajadores de la ciudad, contra uno de los cuales, el jurista Guillem Çaera, el justicia de Aragón había dictado orden de prisión a instancia del vizconde de Vilanova.

-AMV, LM 6, ff. 122v-123r.

Al molt reverent pare en Christ e senyor lo senyor bisbe de València.

Molt reverent senyor:

Per letra d'En Jacme de Celma e en altra manera havem sabud com l'honorable micer Guillem Çaera, missatger d'aquesta ciutat en cort del senyor rey, informat que a instància de mossén Pere Ladró devia esser pres per lo justícia d'Aragó o per lo fet de Xelva, s'és haüd absentar per no venir en mans del dit justícia; del qual encara, e de sos fets, no sabem com li és avengut, jassia hajam ferma sperança que pus vós, senyor, hi siats estat a temps, aquell no haurà encorregut alcuna lesió o dampnatge. De les quals coses, senyor molt reverent, som molt maravellats per dues rahons. La primera, per tant com no creem que rey o senyor al món degués permetre que missatgers de semblant o altra ciutat, anan a ell per fets de sa universitat, fossen per alcuna manera o causa marchats, preses o emparats, per quanta que fos la raó d'aytal empara o presó. La segona, per quant lo dit micer Guillem és estat appellat per lo senyor rey a esser denant ell personalment. E, jassia en lo primer cap o cas, tal presó se pogués per alcuna subtilitat sostenir, emperò, en lo segon cas no ho poria fer, car no seria àls sinó que·l dit micer Guillem, per obtemperar als manaments del dit senyor, fos enganat e malmenat. E per tal, senyor molt reverent, com una de les pus dures coses que a aquesta ciutat porien esdevenir, les quals pendria a major desonor e mirva, sí és que sos missatgers, majorment appellats per lo dit senyor a la sua presència, fossen axí maltractats, e que porien servir en son cas a no obtemperar als manaments del dit senyor, les quals lo dit senyor, per sa mercé, no deu tol·lerar, per tal, senyor molt reverent, ab aquella major cordial affecció que podem, suplicam la vostra reverent senyoria que en aquestes coses vullats esser al dit micer Guillem protector e special guarda, e provehir ab lo dit senyor que-l dit micer Guillem e altres semblants missatgers d'aquesta ciutat, majorment per lo dit senyor appellats a esser denant ell, no venguen en semblants errors o occasions. E a açò, molt reverent senyor, haurem a special gràcia de la vostra reverent senyoria, la qual nostre senyor Déu, per sa mercé, mantenga, prospere e conserve longament. Amén. Scrita en València a XIIII de març, any XCIX.

Los jurats de València, qui·s comanen en vostra gràcia.

\section{4.}

1399, mayo, 31.- Valencia.

Sorprendidos por la noticia de que el rey, presionado por las cortes aragonesas, habría decidido apropiarse del señorío de Chelva con el fin de devolverlo al vizconde, los ediles de Valencia expresan al obispo Llupià su disgusto y las razones de su rechazo de una acción así.

-AMV, LM 6, f. 159r-v.

$\mathrm{Al}$ molt reverent pare en Christ e senyor lo senyor bisbe de València. 
Pare nostre e senyor molt reverent: Sabut havem que la cort d'Aragó ha dit per final resposta al senyor rey de no fer res sobre ço que $l s$ ha demanat tro a tant que-l dit senyor realment aja presa e haüda a sa mà la nostra vall de Xelva per retre aquella al vezcomte. E que-l dit senyor axí'ls ho ha atorgat. E de fet se aparellava e fóra vengut a Xelva si no l'agués enbargat accident de la sua molt excel-lent persona. La qual cosa tenim per la pus stranya del món, no sens gran maravella ne sens mortal desplaer, per les següents raons e altres.

Primera, car és irreparable prejudici e notable diminució de la reyal superioritat e senyoria. E ja per ço lo senyor rey En Johan, de bona memòria, importunament suplicat per part del vezcomte e dels aragonesos a pendre's Xelva en via de seqüestre, no·ls volch escoltar, dehint que, per poder que n'haguessen, no soferria sobiran lo justícia d'Aragó ne altre en regne de València n'és, si tolria un pèl de la sua reyal superioritat.

II $^{a}$, car seria fer lo pus manifest tort del món a nosaltres, qui, ab lo pus just e pus comportable procés qui hanc de semblant raó se fes, axí com pot aparer per lectura d'aquell, haguem e posseïm pacíficament Xelva. E voler-la·ns levar de fet, part no apellada ne oïda, veja tot sà entenent si poria esser major tort ne pus uberta injustícia.

III ${ }^{\mathrm{a}}$, car seria total destrucció d'aquesta ciutat, la qual sens los aemprius de son regne, dats a ella per fur, no pot haver sosteniment ne durada; dels quals aemprius devalla lo procés de Xelva, fet a gran culpa de la part del vezcomte, ab tantes despeses que a penes han compte. Les quals, si lo dit preniment de Xelva se fahia, tothom ha perdudes, no sens irreparable dan de la ciutat, que u féu entre grans càrrechs de censals morts e altres. E, a clar parlar, tot l'engyny e tota la cura del vezcomte és estada e és que, per tal via o altra, de fet gitàs de si lo càrrech de les despeses a gran culpa sua fetes.

IIII ${ }^{\mathrm{a}}$, car tot açò no seria àls sinó un bell engan del vezcomte e dels aragoneses de la sua favor, qui ab ço del nostre volrien fer servii al senyor rey; o no seria me[n]ys que ells dir al senyor rey: 'senyor, destrouits València, e dar-vos-hem'. La qual cosa és de gran abhominació.

$\mathrm{V}^{\mathrm{a}}$, car no seria àls sinó lo senyor rey voler fer procés de part, lo qual no li cové, mas de jutge, parts oÿdes, com sia comun rey e senyor de tots. Ne contrastaria, si era al·legat, segons ja fon diversses vegades en temps del dit senyor rey En Johan, que-l dit preniment de Xelva se fes en via de seqüiestre, perquè les parts aparellades en armes no venguessen a ocasió. Car en açò hac e à dues clares satisfaccions: la una, car tal aparellament de parts en armes no és fet ne's fa en nostre cas; e l'altra, car, hon fer se asajàs, lo senyor rey, qui poderós e sobiran jutge és de tots, pot e deu compestir cascuna de les parts a no venir en armes, majorment car lo venir a les armes no vé per raó de la possessió que nosaltres havem de Xelva, mas vé per la juredicció que·l justícia d'Aragó pretén haver en regne de València, en los lochs poblats a fur d'Aragó, e per la juredicció que nosaltres havem en aquells. Per què, si seqüestre se havia a fer, se hauria a fer de les jurediccions e no pas dels lochs de Xelva. On, senyor, com aquest fet toch pregonament, segons ja és dit dessús, l'interés del senyor rey, toch més avant lo major dan e la pus asenyalada minva que aquesta ciutat pogués haver, e aquella no aja de present altre protector sinó vós, senyor, qui per gràcia de Déu sots nostre prelat e nostre pare speritual, per ço, senyor, en tanta necesitat recorrem a la ajuda de vostra molt reverent paternitat, humilment aquella pregants e suplicants que li plàcia emparar, nós e nostres afers, senyaladament los dessús dits, e per vós matex secretament informar lo senyor rey de les dites raons, e altres, en ajuda nostra, que mils seran vistes a vostra senyoria, e fer ab lo dit senyor rey que 1 dit preniment ces del tot e sia desviat; e, com àls fer no s'i pogués, dir al dit senyor de clar que nosaltres, aytant com sia nos- 
tre legut e humil poder, no sostendrem res àls en contrari, ans guardarem e mantendrem lo seu dret e interés e lo nostre, per feeltat astrets; e que Xelva és e serà, Déu ajudant, axí bé defesa e guardada per a ell e per a nosaltres, que parrà maravella als qui ho veuran o sabran. Les altres coses, si li plaurà, soplesca la vostra transcendent perspicacitat, a la qual plàcia de ço que fet haurà per sa letra nós certificar e consolar, e tenir aquesta letra en secret. E mantenga nostre senyor Déu al seu sant servii vostra molt solemne persona en bona e longa sanitat e vida e altres prosperitats. Amén. Scrita en València a XXXI de matg de l'any XCIX.

Vostres humils fills, etc.

1399, octubre, 22.

Los jurados de Valencia, respondiendo a lo que secretamente les había pedido el rey Martín I por medio del obispo Llupià, exponen su postura en dos aspectos concernientes al asunto de Chelva y del justicia de Aragón.

-AMV, $L M 6$, ff. 240r-241v.

$\mathrm{Al}$ molt reverent pare en Christ e senyor lo senyor bisbe de València.

Molt reverent pare e senyor speritual nostre: Dues ensemps letres, una del senyor rey e altra vostra, havem reebudes. La reyal contenia solament que vós, senyor, largament nos escrivits de certs affers als quals ell havia subirà voler e’ns pregava hi donàssem creença e ho metéssem en obra si jamés complaure e servir li enteníem. En la vostra, senyor, recitat a principi l'estament de la cort dels aragoneses proferints al dit senyor gran colp de moneda per a quitar son patrimoni e per altres propris affers, sots expressa condició: si ell pren e ha Xelva a sa mà, e no en altra manera. Deïts, senyor, dues coses en acabament. La primera, que-1 senyor rey vol saber de nosaltres per quina manera ell pot fer sos affers ab los aragoneses, e $n$ s hen vol donar la fadiga, car a ell cové de fer una resposta o altra si vol finar, e hauria plaer de saber-ne nostra intenció, la qual volria que fos per avenir sos affers e no per torbar-los, però que entenam tots temps que les sues regalies e preheminències ell vol bé guardar e no y tocaria. De què podem compendre $\mathrm{e}$ considerar la gran amor que 1 senyor rey nos ha, per sa benignitat, volent proveir segons nostre consell, creent que aquell li darem tal que serà per avenir e no per fallar. La segona, que, per obrir camí al negoci, parria al senyor rey que València ho degués metre en son poder, e lo vezcomte axí mateix. E al cas que·l vezcomte hi contradiga, no serà bé per a ell, bé que·s pensa no li'n dirà de no. Ne·l senyor rey entén descobrir que València ho meta en son poder, mas esser entre tant segur que·l vezcomte ho meta en son poder. De les quals dues coses volets, senyor, saber nostra intenció e d'aquén intimar aquella al senyor rey secretament. E, segons bé havets acostumat, senyor, per vostra valor e amor cordial, metets-nos en bones esperances.

$\mathrm{E}$, ans de tota resposta, senyor, humilment retem grans e moltes laors e gràcies a nostre senyor Déu, e al senyor rey, e a vós, senyor, de tants e tals benifets, senyaladament de tanta benignitat e gràcia del senyor rey en comunicar a nosaltres sos secrets, no contrastant que toquen interés nostre, e de tantes e tals esperances, e de tanta e tan cordial affecció com amdós mostrats envers nosaltres. Fiam en Déu que·ns darà poder e loch de retribució per exibició de molts e bons servirs.

Ara, senyor, responem a les dues coses dessús tocades, per orde. A la primera: que, jassia la transcendent perspicacitat reyal no fretur de nostre consell ne d'altri; jassia encara fóssem en 
gran perplexetat de dar consell sobre tal fet, per quant toca interés nostre, emperò, nosaltres, moguts e constrets per feeltat, acordam dar lo demanat consell. E sobre açò fom en altra perplexetat major, entre utilitat e honestat. E per mellor intel-ligència d'açò deïm: si los aragoneses posassen la condició justa e honesta, axí com dir «senyor, dam-vos ab condició que res del do no us sia liurat tro a tant que hajats feta justícia en lo fet de Xelva», o que almenys la condició fos potestativa, axí com si·l fet de Xelva tocàs solament lo senyor rey e ells, e fos en facultat del senyor rey tot sol dar o fer la cosa condicionada o complir la condició, no contrastant que fos propri prejudici del senyor rey, en qualsevol d'aquests dos cases poria esser escoltadora la dita condició; mas que·l fet toch interés d'altri e de dret fer no·s deja, no és potestativa tal condició. Donchs, no és àls a ells sinó dir: «senyor, dam-vos ab condició que façats tal tort o tal injustícia», ço és, que de fet, sens conexença de dret, levets Xelva a qui la posseeix e-ns venats justícia per los diners que us dam. En bona fe, tal mercaderia no's cové als demanadors, e molt menys al senyor rey, no solament per aquella quantitat de moneda, mas encara per tot l'or del món. Ne és poqua maravella posar o demanar tal condició, mas creem que ho fa car lurs tractadors de part de la cort són lo vezcomte e altres de la sua favor. En conclusió, deïm que a Déu no plàcia nosaltres donem loch ne consentiment a res que no sia just ne honest, encara que paregués útil en prima faç; e aquest és nostre sen e nostre consell, car fer lo contrari seria consellar contra justícia, la qual cosa la feeltat de què som tenguts al senyor rey no ho permet.

A la segona cosa responents, deïm, segons ja diverses vegades dixem a aquest senyor rey e al senyor rey En Johan, de bona memòria, frare seu, ladonchs vivent, que, com aquest fet toch capital prejudici del senyor rey e de la sua corona e preheminència, com no sia àls sinó constituir-li subirà en aquest regne, axí com en Aragó, e tolre-li les sues superioritats e preheminències reyals, la qual cosa és esquivadora axí com a foch cremant. E sol esmentar que, sia mès en mà del dit senyor o d'altri, sia dar-hi qualque consentiment o paciència e crèxer lo prejudici e metre en dubte les coses notòries e manifestament nostres. Per açò, més que per àls, ho havem tots temps esquivat, constrenyent-nos-hi encara la forma del sagrament de feeltat qui-s féu al senyor rey per nostres predecessors ladonchs quant fo feta edició dels furs de València, foragitat del regne d'aquella lo fur d'Aragó, la qual forma de sagrament se repeteix a temps de quascun novell rey.

Examine, donchs, e veja la vostra molt reverent e benigna paternitat si en nosaltres és àls de fer, car no'ns ho par. E, per ço, a la dita paternitat pregam e supplicam que a aquella plàcia totes e sengles les dites coses entesament (sic) referir al senyor rey, e a ell supplicar e induir a continuació de la sua gràcia e affecció envers nosaltres, e a sa valor e honestat e justícia, per la qual los reys són e regnen, e fer en tot cas que·l dit senyor se tenga per bé content de nosaltres. E serà cosa la qual haurem en singular e notable do e gràcia de la vostra molt reverent paternitat, la qual, en bona e longa sanitat e vida e altres prosperitats, mantenga nostre senyor Déu per sa mercé. Scrita en València a XXII d'octubre de l'any XCIX.

Vostres humils fills e affectuoses servidors, qui·s comanen en vostra gràcia, los jurats de València.

6.

1399, diciembre, 19.- Valencia.

Los ediles valencianos, respondiendo por medio de Hug de Llupià a Martín el Humano, que quería conocer su parecer sobre un arbitraje real entre la ciudad y el vizconde en el asunto de 
El justicia de Aragón frente a la ciudad de Valencia. Un conflicto entre oligarquías territoriales...

Chelva, se muestran contrarios al reconocimiento de la jurisdicción del justicia de Aragón, cuyas actuaciones perjudicaban gravemente a los valencianos.

-AMV, LM 6, ff. 268r-269r.

$\mathrm{Al}$ molt reverent pare en Christ e senyor lo senyor bisbe de València.

Molt reverent pare e senyor: Largament e bé per vostra letra som certifficats com és intenció del senyor rey, per sa mercé, conformant-se ab la nostra, que en lo fet de Xelva no-s faça res que sia prejudici a ses regalies e preeminències ne a altre dret seu ne nostre. E que, estant ell en Aragó, no’s deu dar loch que-1 fet aquell sie mès en son poder, mas que, estant fora d'Aragó, si sens prejudici pot esser, entén lo dit senyor que deja esser mès o posat en son poder per nostra part e per la del vezcomte. Més avant, lo dit senyor, seguint ara nostre voler e faent alcuns partits e limant més lo fet, diu que d'aquell fos fet compromés en poder de la senyora reyna, e que ella anàs a Tortosa o en altra part de Cathalunya per fer sa determenació, e que no troba lo dit senyor ab tot son consell que per aquesta via fos fet prejudici a una part ne a altra. E per ço lo dit senyor en tota manera vol haver sobre aquest fet nostre consell e resposta. Senyor, a vostra molt reverent paternitat supplicam que us plàcia bé avertir açò qui-s segueix. Lo més o lo tot del prejudici, a nostre sen e parer, està en lo procés del justícia d'Aragó qui, a desplaer de natura, vol e s'esforça esser nostre jutge, e pus subirà en aquest regne que·l senyor rey, e'ns ha fet e·ns fa de fet lo procés que sabets, e ha e té condempnats, que ell appella encartats, molts dels majors d'aquesta ciutat, e fetes, e fer no cessa, diverses e moltes marques de vehins d'aquella. Que·ns valria, donchs, senyor, finar lo fet en via d'arbitració o altra ab lo vezcomte per son interés, e que 1 prejudici tan fort e la nafra tan mortal del dit justícia romangués en nosaltres per a tots temps esdevenidor, no sens gran prejudici de la preeminència $\mathrm{e}$ dignitat reyal? Al qual prejudici seu e nostre lo dit senyor tro ací no ha dat, ne par que·s pogués dar per la dita arbitració, remey covinent, ans per tal metiment en mà compromissària seria vist esser fortifficat lo dit prejudici e resfrescada la dita nafra. Donchs, com en açò estia lo més de nostre mal e greuge, e de nostre prejudici, e no menys del senyor rey, veja e considere la sua e vostra subirana perspicacitat quin o qual remey pot esser dat al dit prejudici. Per què, senyor, lo consell e la resposta que al senyor rey plau saber e haver de nosaltres sobre aquest pas, par a nosaltres sia e deja esser aytal. Cert és que 1 dit senyor, per son accident e per recuperació e conservació, Déu ajudant, de sanitat de la sua molt excel-lent persona, deu exir dins breus dies d'Aragó e venir-se'n en aquesta ciutat, que és terra calda o temprada per a sa complexió, en la qual cobrarà, fiam en Déu, plena sanitat de cos e de ànima. E que, ans de totes coses, lo dit senyor deu relevar lo dit prejudici tan soberch a ell e a ses regalies e preeminències e a nosaltres. E ladonchs, per ell request lo consell d'aquesta ciutat sobre los partits ara moguts per lo dit senyor o altres en lo dit fet, tant com toqua l'interés del vezcomte e nostre, ladonchs, lo consell porà mils elegir un d'aquells partits, e respondre'n clar al dit senyor, ço que ara fer no pot bonament estant axí prejudicada, marchada e maltractada per lo dit justícia d'Aragó. E plàcia a vós, senyor, dar açò bé entendre al senyor rey e fer que haja per acceptable nostra present resposta com a tota sana intenció fer-se deja. E mantenga nostre senyor Déu vostra molt solemne persona en sanitat e prosperitat longament. Amén. Scrita en València a XIX de deembre de l'any XCIX.

Humils fills e affectuoses servidors qui·s comanen en vostra gràcia, los jurats de València. 
1400, enero, 27.- Valencia.

Los jurats de Valencia dan cuenta a Hug de Llupià de la negativa del consell general de la ciudad a las propuestas sobre el caso de Chelva y del justicia de Aragón que presentaron Pere d'Artés y el batle general en nombre del rey, acerca de cuyo contenido los consellers habían jurado previamente guardar secreto.

-AMV, LM 6, ff. 291v-293v.

Al molt reverent pare en Christ e senyor lo senyor bisbe de València.

Pare e senyor molt reverent: Pus plagué a la reyal excel-lència e a la vostra paternitat de nosaltres, jurats, comunicar al consell general d'aquesta ciutat les letres e cèdula del dit senyor rey e vostres toquants lo fet de Xelva, axí és estat enseguit, ço és, que huy tenguem consell general. E, reebut primerament sagrament de tots e de cascun dels consellers de tenir-ho secret, les dites letres e cèdula foren lestes spaciosament al dit consell. E enaprés foren appellats al dit consell mossén Pere d'Arters e lo batle general d'aquest regne, los quals, ab moltes e diverses rahons, fort affectuosament, informaren lo dit consell, induints aquell a fer les coses per lo senyor rey demanades e per vós, senyor, scrites. E, aprés aquells foren partits del dit consell, per esser mils descutides les coses en les dites letres contengudes, foren apuntades en $\mathrm{IIII}^{\mathrm{e}}$ caps o punts, a cascun dels quals foren repetides les raons de vostra letra faents per aquell cap o punt. E d'aquén, tots e sengles del dit consell, singularment e per orde, dixeren lurs vots ab diverses e moltes raons, pro e contra, a lur liberal voler. E per ço, lo consell durà de la hora de mija tèrcia tro a vespres sonants. E foren los dits IIII ${ }^{\mathrm{e}}$ caps o punts aquests.

Primer, si la cèdula era bastant a nostra indempnitat o preservació de nostre prejudici.

Segon, si era factible que·l dit fet per via de compromés fos mès en poder e mà de la senyora reyna.

Terç, si de la longa estada del senyor rey en Çaragoça, no sens gran enuig de la sua molt excel-lent persona, en tant que n'havia sostengut e'n sostenia accident de febra quartana, e més avant de la sua aturada, si·s covenia fer allí, d'ací avant havia càrrech alcú aquesta ciutat, no volent passar a les coses en vostra letra contengudes.

E quart e derrer, si-s devia dar loch a la demanda que al senyor rey, quasi per son derrer partit, plahia fer a aquesta ciutat que de son grat li donàs Xelva.

E, jassia moltes e longues disputes e rahons hagués sobre cascun dels dits partits, e sobre les raons de vostra letra tocant aquell partit, emperò, a la final, tot lo consell en gran e total concòrdia, sens discrepància d'alcú, concordà en ço e segons qui·s segueix.

Primerament, sobre lo primer punt concordà que la dita cèdula no era bastant a nostra indempnitat ne a preservació de nostre prejudici, senyaladament per tal car poria s'esdevenir que la dita cèdula no vendria a alcun esser o perfecció, e nosaltres tendríem ja a dors lo mortal e irreparable prejudici, sens sperança d'altre remey. Car, jassia lo senyor rey, estant en Cathalunya, appellàs lo justícia d'Aragó, e encara que ell no comparegués lo senyor rey pronunciàs lo procés feit per lo dit justícia d'Aragó esser nul·le, axí com a feit per jutge incompetent, emperò, lo justícia d'Aragó tots temps al·legaria que la sentència no li poria noure com lo senyor rey, segons ell aferma, no sia son jutge, e ell no sia tengut comparer denant lo dit senyor. E, jassia 
nosaltres mostràssem nostra sentència en escrits, la qual de dret valria, però, ell mostraria que de fet hauria haüt propòsit de sa intenció per ço com lo vezcomte hauria recobrat Xelva, e per ço a nosaltres seria engenrat lo dit prejudici irreparable. E si lo justícia d'Aragó comparia, ell poria al-legar tals prejudicials que allongaria lo procés a gran temps, e nosaltres romandríem en aquest endemig despullats de nostra justícia. E, senyor, nosaltres no dubtam que ço que 1 senyor rey nos prometés que no u observàs; mas veem e som certs que les preheminències reyals $\mathrm{e}$ nostres privilegis no poden esser satisfets ne tornats a degut estament tro a tant que 1 senyor rey, appellat lo justícia d'Aragó e nosaltres, haja declarat lo procés del justícia d'Aragó esser nul·le, e·ns haja feit tornar e restituir moltes e diverses quantitats de peccúnia que lo dit justícia, per raó del dit procés, contra Déu e justícia, ha preses e robades de habitadors d'aquesta ciutat, en gran lesió de les superioritats reyals e prejudici nostre, de les quals nos forem bé reintegrats sinó que, ab ulls cluchs, per servii del senyor rey e per no donar-li destorb en sos feyts, nós ne som estats tro ací.

Sobre lo segon punt, fon concordat que per consegüent lo dit compromés no era factible, car puix prenia fonament e remey de o en la dita cèdula, e aquella no complia ne podia haver loch, segons és dit; que per consegüent no’s devia parlar del dit compromés, majorment car, si per ventura nosaltres volíem o demanàvem alcuna cosa delicada o graciosa, o en altra manera no justa ho no honesta ha rahó, què dir? Mas que nosaltres tots temps hajam demanat e demanàvem cosa justa e honesta e digna de exaudició, és saber, justícia, la qual a tota senyoria divinal e temporal pot esser demanada, cosa és que no reeb ne deu reebre denegació, dilació ne altre embargament.

Sobre lo terç punt, sens tota al·legació se pot veure per tot sà entenent que nosaltres tal càrrech o colpa fom e som e serem, Déu ajudant, tan quitis com fos haüt sant de peccat, e axí appar per demostrativa e inconventible raó permanent en acte. A vós, senyor, e a tota sàv[i]a testa demanam: ¿què s'atany la cort d'Aragó ab lo fet de Xelva, qui és d'aquest regne e de persona singular, en lo qual no ha greuge del senyor rey ne de official seu? E, per consegüent, ¿d'on s'i vé que la dita cort ne faça e·n forme greuge, majorment tan desraonable, ab tota reverència parlan? Car, almenys si demanave per greuge que 1 senyor rey hi fes justícia en loch e temps covinents, no seria de tanta estranyea. Mas dir que daran al senyor rey certa quantitat de moneda si, sens procés e sentència e sens tota coneguda de dret, contra tota ley divinal e humanal, lo senyor rey tol a nosaltres Xelva e la do al vezcomte, del qual, per sa uberta colpa e resistència, e ab procés tan solemne e tan justifficat, la ciutat la hagué e la ha tenguda e té pacífficament e ab just títol, no és àls dir o demanar sinó que·l senyor rey nos vena justícia per diners. Pot encara esser dit altra cosa: que la cort vulla fer do al senyor rey de ço del nostre, e no poch, esguardan com e quant costà a aquesta ciutat lo fet de Xelva, e com e en quant li és cara. En veritat, senyor, tal dir o demanar no cové a tan sàvia e tan solemne cort, e menys a soferir nosaltres, e molt menys a escoltar al senyor rey com a ver rey e senyor justiciable de tots. E par a alcuns sia pocha maravella d'ells dir o demanar tal cosa, esguardan que ls tractadors de la dita cort són lo vezcomte mateix, nostre adversari, e sos principals fautors. La qual cosa, si plagués a Déu e al senyor rey, no degra esser consentida. E si lo justícia d'Aragó e la cort, per esforçar injustícia, fan estar aquí lo senyor rey, malalt e ab perill de sa persona e en gran dan de tots sos regnes e terres, les quals no pot visitar, ¿quin mal hi merim nosaltres, qui solament demanam e defenem justícia, de la qual ja en lo començament de la cort d'Aragó per nostres missatgers lo dit senyor fon supplicat? Concloent, donchs, sobre lo dit terç punt: veja la vostra molt reverent saviea si de la longa estada e de l'enuig e dan del senyor rey és en 
causa altri sinó los faedors e consentidors de les dites coses, e no en res de nosaltres, qui gran temps ha passat havem desijat e desijam cordialment la sua venguda e facial vista, e qui en res d'açò no havem tort.

Sobre lo quart punt és concordat que la ciutat en servir lo senyor rey no ha acostumat esser avara; mas, esguardan com e quant va a la honor e fama de la dita ciutat en lo fet de Xelva, e ab quantes fadigues, treballs, dans e despeses aquell fet fo acabat, e li van tots sos privilegis, los quals ha carament comprats ab efusió de sanch; e, si en res d'aquest procés de Xelva era flixat, sinó solament a pura justícia, la ciutat en sos privilegis e aemprius no seria res preada, ans seria causa de diminució d'aquella, segons és estat de moltes altres ciutats, qui per flixar en lurs privilegis e drets són estades destançades, ço que lo senyor rey no creem que vulla d'aquesta ciutat, car servit ha a ell e a sos predecessors altament e bé, e és apparellada servir; e per açò, feeltat nos costrenga a evitar lo dit cas e no donar loch a enderroch de la dita ciutat, ne que barons o ciutadans o altres grans hòmens assajen de prejudicar aquella en ses franquees e libertats; e guardar açò és fer lo servii e fets del senyor rey; e la ciutat, per les dites rahons, ha Xelva molt en car. No·s pot acostar a la intenció del consell de acordar-se a tal demanda, majorment car par que ara·s vulla verificar ço que·l vezcomte e altres parents e amichs seus en temps passat han dit, ço és, que ta[ntes m]aneres s'i assajarien que, per un cap o per altre, ell cobraria Xelva [se] ns cost. No serà veritat, si Déus ho vol.

Senyor molt reverent, com les dites concordances proceesquen de gran justícia, egualtat e raó, e en aquelles vaja a aquesta ciutat tant de sa honor e dan que pus no pot, e vós, senyor, siats pare speritual d'aquella e dejats esser son protector e ajudador, supplicam reverentment a la vostra paternitat que a aquella plàcia totes e sengles les dites coses haver per agradables, e aquelles explicar al senyor rey, e supplicar e induir aquell que les haja per acceptables. E açò haurem en singular do e notable gràcia de vostra molt reverent paternitat, la qual nostre senyor Déu, per sa mercé, conserve en bona e longa vida e altres prosperitats. Amén. Scrita en València, a XXVII dies de jener, en l'any de la nativitat de nostre Senyor MCCCC.

Humils fills e affectuosos servidors, qui·s comanen en vostra gràcia, los jurats de València.

Pare e molt reverent senyor: Per ço com creem que la letra major que us trametem en tot cas volrà veure lo senyor rey, trametem a part, secretament, a la vostra molt reverent paternitat la present, la qual, si vostre plaer serà, tendrets en pregon secret. Senyor, certs som e és massa notori que tot aquest tracte e enburlament de la cort d'Aragó fan principalment l'archabisbe e sos adherents per sol esguart d'aquell e en favor del vezcomte, en no poch destrich e destorb dels affers del senyor rey, e contra dret e justícia. E pus lo dit archabisbe, contra tota justícia, en favor del dit vezcomte e en destrucció d'aquesta ciutat, de la qual vós, senyor, sots pare speritual, fa les dites coses, supplicam vostra molt reverent paternitat que, axí com bé havets acostumat treballar tots temps per la dita ciutat e per honor e per los affers d'aquella, vullats e us plàcia fer venir los dits affers a lur orde de justícia, per manera que les preheminències reyals sien conservades, e la honor e les libertats e franquees de la dita ciutat romanguen intactes, e lo dit archabisbe no`s puxa gloriejar sobre son propòsit. E pus ara no deïm, axí com no cal a testa de tan gran saviea, mas que conserve nostre senyor Déu, per sa mercé, la vostra molt reverent e solemne persona en bona e longa sanitat e vida, e al(tres) prosperitats. Amén. Scrita ut supra.

Humils (etc.) 
El justicia de Aragón frente a la ciudad de Valencia. Un conflicto entre oligarquías territoriales...

8.

1400, febrero, 12.- Valencia.

Los jurats de Valencia informan secretamente a Hug de Llupià de la respuesta negativa del consell general a las peticiones formuladas por el rey Martín con relación al asunto de Chelva, tras ser sometidas a su consideración.

-AMV, LM 6, f. 305r-v.

Al molt reverent pare en Christ e senyor lo senyor bisbe de València.

Pare nostre e senyor molt reverent:

En l'altra letra, sots data d'aquesta, que a vostra senyoria ara trametem, havem callat scientment ço que dejús en la present és contengut, com requira pregon secret e no seria raó que·s mostràs en l'altra letra, la qual de necessitat és mostradora, per què ab aquesta, secretament, a vostra senyoria notifficam que, aprés la explicació de l'honorable En Ramon Fiveller de que·s fa menció en la dita altra letra, nosaltres, en aquell mateix dia, a les vespres, per mils discutir lo fet, tenguem consell de cambra ans del general, en lo qual consell de cambra se delliberà que no's podia dar ne·s daria loch per la vida a la explicació del dit En Ramon sens lo consell general. E en aquell mateix dia vench e plegà ací l'onorable En Pere Gençor, nostre missatger, e en l'endemà tenguem lo consell general, en lo qual, sens tota discrepància, fo concordat que no's podia ni devia donar loch a les coses per lo dit En Ramon proposades e per lo senyor rey e per vós, senyor, scrites, segons en l'altra letra a vós, senyor, havem escrit. E, veent tot açò lo dit En Pere Gençor, ell apartà nosaltres, jurats, e los advocats e síndich e escrivà, e reebut de cascun de tots per ell sagrament de tenir-ho secret, liurà a nosaltres una letra de creença de vós, senyor, en virtut de la qual ell explicà a nosaltres com vós, senyor, e vostre noble frare, mossén Ramon, havíets apuntada e contemplada una cèdula enclosa dins nostra derrera letra que a vostra senyoria havíem tramesa per final resposta del fet de Xelva. E com apparegués a vós, senyor, e a ell que la dita cèdula tocava aempre, que amdós hauríets sobre aquell aempre feta tal resposta que pus alta ne pus valerosa no's pogra dir ne fer de pare, de frare, de fill o d'altre qualsevol acostat grau de parentesch ne de dilecció a sos semblants. En bona fe, senyor, d'açò haguem tan sobirà plaer que a alcuns ne rodaren los ulls en aygua de cordial amor. E volríem que, a honor e bé vostre, senyor, e de vostre frare, Déu portàs matèria en que ho poguéssem mostrar per obra. E d'açò escrivim ara a vostre frare. Més avant, lo dit En Pere Gençor, ajustant a nosaltres plaer sobre plaer, nos dix que, liurada per vós, senyor, al senyor rey nostra letra e la vostra dessús dita del dit final acort, lo senyor rey tench son gran consell, en lo qual, com les primeres oppinions fossen qu·el dit senyor fes alcuns proceïments contra nosaltres, vós, senyor, mostrant ubertament la paternal affecció que havíets e havets envers aquesta ciutat e sos habitadors, fills sperituals vostres, hauríets dit tot clar al senyor rey, que fos sa mercé no apparellar-vos en res que fos contra nosaltres, car no ho poria sofrir vostre paternal cor, e altres mellors paraules; però, que les altres e finals opinions foren, e axí fon conclós, que·l senyor rey, si àls fer no podia ab los aragoneses, com lo consell de sos metges fos e li protestàs tots dies que isqués d'aquí e anàs als banys de Caldes, per la cara salut de la sua molt excel·lent persona s'ic partís, e que no·s parlàs pus del fet de Xelva. O Déu! He quanta consolació aportaren a les nostres entràmenes totes les dites paraules, de les quals no poríem retre condignes laors e gràcies a la sancta divinitat e a la vostra reverència paternal! Però, retem-los aquelles més e majors que podem a present, confiants en la divinal misericòrdia que·ns darà loch e cas de mostrar-ho per obra a vós, senyor, e a 
mossén Ramon. E pus ara no deïm, mas que posam, nós e lo nostre, en les vostres paternals e sagrades mans. E plàcia a la Sancta Trinitat que longament e bé mantenga vostra molt solemne persona en vida, sanitat e altres prosperitats. Amén.

Scrita en València, a XII de febrer de l'any MCCCC.

Humils fills e affectuoses servidors, qui·s comanen en vostra gràcia, los jurats de València.

\section{Referencias bibliográficas}

CÁTEDRA, P. M. (1985-1986), «Acerca del sermón político en la España medieval. (A propósito del discurso de Martín el Humano en las cortes de Zaragoza de 1398)», Boletín de la Real Academia de Buenas Letras de Barcelona, XL.

COLÓN, G., V. GARCÍA, eds. (2007), Furs de València, Extravagants, I, Barcelona, Barcino.

DANVILA, M. (1905), Estudios críticos acerca de los orígenes y vicisitudes de la legislación escrita del antiguo reino de Valencia, Madrid, Establecimiento tipográfico de Jaime Ratés.

DE RIQUER, M. (1980), Història de la literatura catalana, 2 vols., Barcelona, Ariel.

EIXIMENIS, F. (ed. 1983), De sant Miquel Arcàngel. El quint tractat del «Libre dels àngels», ed. de C. Wittlin, Barcelona, Curial.

GIMÉNEZ, A. (1897), «El Justicia de Aragón, Juan Giménez Cerdán», Revista de Archivos, Bibliotecas y Museos, I.

GIRONA, D. (1916), Itinerari del rey En Martí (1396-1410), Barcelona, Impr. de Henrich y $C$.

GUAL, M. (1947-1948), «Contribución al estudio de la territorialidad de los Fueros de Valencia», Estudios de Edad Media de la Corona de Aragón, III, 262-289.

IVARS, A. (1921), Dos Creuades Valenciano-Mallorquines a les Còstes de Berbería. 1397-1399, València, Imp. Olmos y Luján.

JAVIERRE, Á. L. (1942), María de Luna, reina de Aragón, Madrid, CSIC.

LÓPEZ, C. (2005), Nobleza y poder político en el reino de Valencia (1416-446), Universitat de València.

NAVARRO, G., ed. (2008), Cortes del reinado de Martín I, Acta Curiarum Regni Aragonum, tomo VI, 2 vols., Zaragoza, Gobierno de Aragón e Ibercaja.

OLMOS, E. (1949), Los prelados valentinos, Valencia, Semana Gráfica S. A.

PALACIOS, B. (1975), La coronación de los reyes de Aragón, 1204-1410. Aportación al estudio de las estructuras políticas medievales, Universidad de Zaragoza.

PERALES, J. B. (1880), Décadas de la historia de la insigne y coronada ciudad y reino de Valencia. Tercera parte. Continuación de las Décadas que escribió el Licenciado y Rector Gaspar Escolano, III, Valencia/Madrid, Terraza, Aliena y Compañía.

RODRIGO, M. (1975), «La Unión valenciana y sus protagonistas», Ligarzas, 7 (1975), 133-166. 
El justicia de Aragón frente a la ciudad de Valencia. Un conflicto entre oligarquías territoriales...

RODRIGO, M., ed. (2011), Melcior Miralles: Crònica i dietari del capellà d'Alfons el Magnánim, Universitat de València.

RUBIO, A. (1989), «El segle XIV» en Història del País Valencià. Volum II. De la conquesta a la federació hispànica, Barcelona, Edicions 62.

- (1999), «El ganado de Valencia y los pastos del reino. El avituallamiento urbano bajomedieval como factor de conflictividad», Boletín de la Sociedad Castellonense de Cultura, 75, 651-719.

- (2012), El patriciat i la nació. Sobre el particularisme dels valencians en els segles XIV i XV, 2 vols., Castelló-Barcelona, Fundació Germà Colón Domènech, Publicacions de l'Abadia de Montserrat.

SANCHIS, J. (1932), Dietari del capellá d'Anfos el Magnànim, Valencia, Acción Bibliográfica Valenciana.

SEMPERE, V. F. (2014), «Els Centelles, senyors de Nules, Rebollet i Oliva», Cabdells: Revista d'Investigació de l'Associació Cultural Centelles i Riusech, 4.

SESMA, J. Á. (1987), «Estado y nacionalismo en la Baja Edad Media. La formación del sentimiento nacionalista aragonés», Aragón en la Edad Media, 7, 245-273.

- (1988), «El sentimiento nacionalista en la Corona de Aragón y el nacimiento de la España moderna», en A. Rucquoi (ed.), Realidad e imágenes del poder. España a fines de la Edad Media, Valladolid, Ámbito.

TASIS, R. (1957), Pere el Cerimoniós i els seus fills, Barcelona, Ed. Vicens-Vives.

VIDAL, E. (1974), Valencia en la época de Juan I, Universidad de Valencia.

ZURITA, J. (ed. 1967-1985), Anales de la Corona de Aragón, edición de A. Canellas, Zaragoza, Institución Fernando el Católico. 
